\title{
DESEMPENHO DE BOVINOS CONFINADOS COM RAÇÃO A BASE DE BAGAÇO DE CANA-DE-ACUÚCAR AUTO-HIDRO- LISADO, LEVEDURA E VINHAÇA, SUB-PRODUTOS DA INDÚSTRIA DE AÇÚCAR E ÁLCOOL
}

\author{
MARIO CELSO FERNANDES LACÔRTE \\ Engenheiro Agrônomo
}

Orientador: Prof. Dr. MAX LAZARO VIEIRA BOSE

Dissertação apresentada à Escola Superior de Agricultura "Luiz de Queiroz", da Universidade de São Paulo, para obtenção do título de Mestre em Agronomia. Área de concentração: Nutrição Animal $\theta$ Pastagens.

PIRACICABA

Estado de São Paulo - Brasil

Outubro - 1987 
Aos meus pais

JOSE PAULO P RARIA DTRCE

\author{
A minha esposa \\ ANA LUCIA \\ Aos meus filhos \\ LUIS EDUARDO E MARINA
}

DEDTCO. 
.iii.

\section{HOPENAGENS ESPECIAIS}

Ao Eng ${ }^{\circ}$ LAMARTINE NAVARRO $\mathfrak{J}_{\boldsymbol{T}}$, Presidente da Destilaria Alcídia S/A, por sua luta permanente em favor do desenvolvimento tecnológico do setor alcoojeiro.

Ao Sr. LUIZ LEITh́o PESSOA, Sócio da DECASA - Destilaria de Ålcoo1 Caiuâ S/A, pela inestimâve1 colaboração na execução desse trabalho. 


\section{AGRADECIMENTOS}

Ao Prof. Dr. Max Lazaro Vieira Bose, pela orientação dedica $\mathrm{da}$;

Ao Prof. Dr. Irineu Umberto Packer, pelo auxílio na anälise estatística;

Ao Prof. Dr. Tomaz Caetano Ripoli, pelas sugestões e amiza de ;

Ao Prof. Dr. Vidal Pedroso de Faria, pela cooperação no in cio deste trabalho;

Ao Prof. Dr. Anivaldo Pedro Cobra, pelo apoio no início do curso de Mestrado;

Ao Eng Agr: M.S. Ricardo Burgi, pelas sugestões na elabora ção do trabalho e amizade;

Ao Eng: Agr: Ari Josê Fernandes Lacôrte, pelo auxílio na condução do experimento e amizade;

A Enga Agrạ. Maristela Neves Conceição, pela cooperação; 
A Técnica de Laboratório Ana Maria Zani de Moura, pela rea lização das anālises laboratoriais;

Aos Eng: Agr: Antonio Dancs Jacinto e Onôrio Kitayama, Dire tores da DECASA - Destilaria de Âlcool Caiuá S/A, pelas sugestōes na elaboração do plano de pesquisa e apoio na condução do trabalho.

A DECASA - Destilaria de Ålcool Caiuá S/A, pelo financiamen to da pesquisa;

A Destilaria Alcídia S/A, pelo fornecimento do bagaço auto-hidrolisado;

Aos companheiros da PLANO CONSULTORIA AGROPECUARIA, pela co operação e amizade. 


\section{IMDICE}

pägina

RESUMO $x i$

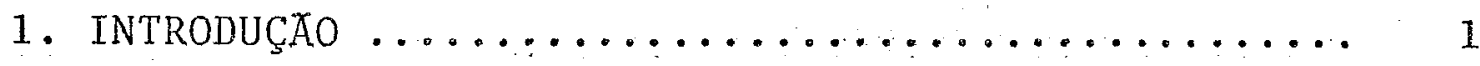

2. REVISAOO DE LITERATURA ................... 3

2.1. Bagaço Auto-Hidrolisado ................ 3

2.2. O Concentrado de Vinhaça (Levedura de Vinha-

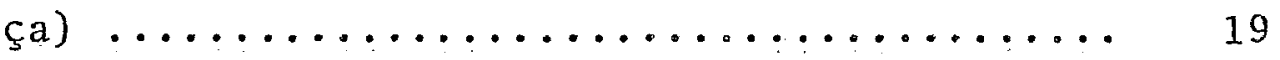

2.3. A Levedura de Sangria ............... 30

3. MATERTATS E METODOS ..................... 37

3.1. Condiçōes de Hidrólise do Bagaço ......... 38

3.2. Teste de Ganho de Peso ................. 40

3.3. Procedimento Estatístico .............. 44

4. RESULTADOS E DISCUSSÃO .................. 45

4.1. Consumo e Conversāo Alimentar ........... 45

4.2. Resultados de Ganho de Peso .............. 52

5. CONCLUSOES .......................... 57

BIBLIOGRAFIA CITADA $\ldots \ldots \ldots \ldots \ldots \ldots \ldots \ldots \ldots \ldots \ldots$

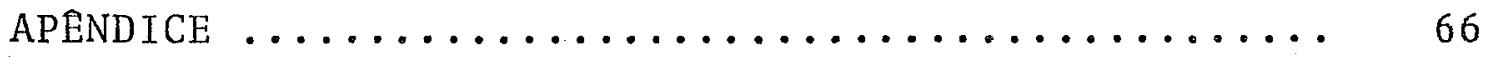




\section{LISTA DE TABELAS}

página

1. Resultados de tratamento com pressão de vapor sobre a digestibilidade in vitro da M.S. (DIVMS)

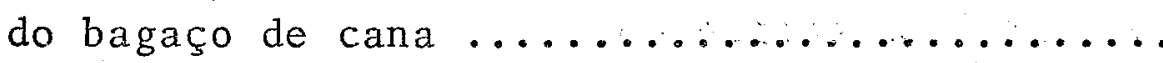

2. Digestibilidade verdadeira in vitro da M. S. (DIVMS) do bagaço auto-hidrolisado em função da pressão e do tempo de tratamento...........

3. Resultados mëdios de anālises bromatológicas do bagaço auto-hidrolisado (BAH) $17 / 5$ e do bagaço in natura $\ldots \ldots \ldots \ldots \ldots \ldots \ldots \ldots \ldots \ldots \ldots$

4. Consumo de matêria seca de bovinos alimentados com rações completas à base de bagaço auto-hi drolisado com $17 \mathrm{kgf} / \mathrm{cm}^{2}$ de pressão durante 5 minutos $($ BAH $-17 / 5) \ldots \ldots \ldots \ldots \ldots \ldots \ldots$

5. Composição da vinhaça de cana em sólidos totais e orgânicos e em elementos minerais ..........

6. Anâlise quîmica bromatológica de biomassa füngica $\ldots \ldots \ldots \ldots \ldots \ldots \ldots \ldots \ldots \ldots \ldots \ldots \ldots \ldots \ldots \ldots$ 
7. Rendimentos médios obtidos na produçăo de vi nhaça concentrada ................... 26

8. Composição bromatolögica de diferentes tipos de leveduras e do fare10 de algodão (em 100\% $\mathrm{da}$ M.S. $\ldots \ldots \ldots \ldots \ldots \ldots \ldots \ldots \ldots \ldots \ldots \ldots \ldots$

9. Composição das rações e consumo estimado em $\mathrm{kg}$ de matéria original (M.O.) por cabeça por

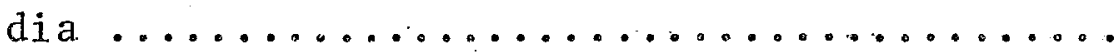

10. Composição das rações completas em princípios

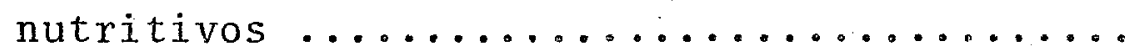

11. Consumo das rações completas, médias semanais por tratamento $\ldots \ldots \ldots \ldots \ldots \ldots \ldots \ldots$

12. Ganho de peso diärio (G.P.D.) mëdio - 112

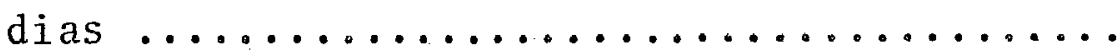

Tabe1a 1 (Apêndice)

Anảlise bromatológica dos alimentos utiliza-

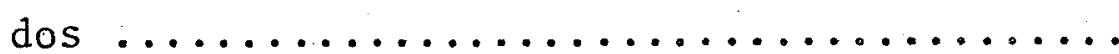


Tabela 2 (Apêndice) Anâlise bromatológica das rações completas ... 68

Tabela 3 (Apêndice)

Anảlj.se de minerais da levedura e do concentrado de vinhaça ................... 69

Tabela 4 (Apêndice)

Peso inicial, final e ganho de peso diärio ... "70

Tabela 5 (Apêndice)

Anâlise de variância - peso inicial ..........

Tabela 6 (Apêndice)

Análise de variância - peso final .......... 71

Tabela 7 (Apêndice)

Anälise de variância - ganho de peso diārio .. 71 


\section{LISTA DE FIGURAS}

página

1. Efeito da pressão e tempo de tratamento sobre a digestibilidade do bagaço de cana .........

2. Digestibilidade verdadeira in vitro da matéria seca (DIVMS) do bagaço hidrolisado, em funçäo

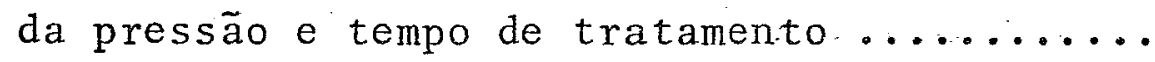

3. Consumo médio de mistura de ração, em função da proporção de bagaço auto-hidrolisado (BAH)

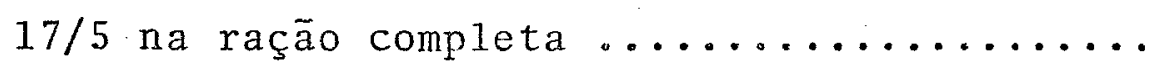

4. Esquema da produção de âlcool e de levedura para obtenção de concentrado proteico .......

5. Esquema do equi.pamento de auto-hidrölise do

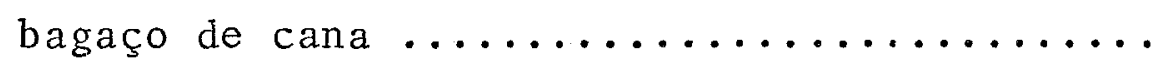

6. Evolução do consumo de ração completa durante o tempo de confinamento (em Matéria Originalм0) $\ldots \ldots \ldots \ldots \ldots \ldots \ldots \ldots \ldots \ldots \ldots \ldots$

7. Evolução do ganho de peso durante o confinamento $\ldots \ldots \ldots \ldots \ldots \ldots \ldots \ldots \ldots \ldots \ldots$ 
DESEMPENHO DE BOVINOS CONFINADOS COM RAÇÃO À BASE DE BAGAÇO DE CANA-DE-AÇUCAR AUTO-HIDROLISADO, LEVEDURA E VINHAÇA, SUB-PRODUTOS DA INDÚSTRIA DE AÇUCAR E ÁLCOOL

Candidato: MARIO CELSO FERNANDES LACÔRTE Orientador: Prof. Max Lazaro V. Bose

\section{RESUMO}

o uso de levedura seca ou concentrado de vinhaça, associados ao bagaço de cana-de-açúcar auto-hidroli sado (BAH) em rações de confinamento, foi testado em comparação com rações tambëm à base de $B A H$, contendo farelo de algodão como fonte de proteina.

Durante 122 dias foi conduzido um experimen to de ganho de peso com novilhos confinados (peso vivo inicia1 $=.316 \mathrm{~kg}$ ). As rações formuladas para proporcionar ga nho de peso de $1 \mathrm{~kg}$ por dia, continham $50 \%$ de BAH e $12,7 \%$ da fonte de proteína (farelo de algodão ou concentrado de vinhaça ou levedura), $17,8 \%$ de milho e $12,5^{\circ}$, de cana inteira picada como volumosos complementar.

o ganho de peso médio foi de 843,989 e 580 g/cabeça.dia, para rações contendo farelo de algodão, levedura e concentrado de vinhaça, respectivamente. 
As rações contendo levedura e farelo de algo dão proporcionaram ganhos de peso significativamente superiores $(P<0,01)$ quando comparadas com a ração contendo concentrado de vinhaça, não ocorrendo diferenças significativas entre as duas primeiras, nem mesmo ao nïvel de $5 \%$, pe 10 teste de Tukey.

Conclui-se que a levedura seca pode substituir totalmente o farelo de algodão em raçōes completas pa ra confinamento contendo bagaço de cana auto-hidrolisado, devendo-se, entretanto, considerar os aspectos econômicos dessa substituição. 


\section{PERFORPANCE OF FEEDLOT WITH RATION BASED ON AUTO HYDROLYSED SUGAR CANE BAGASSE, YEAST AND VINASSE, BY-PRODUCTS OF THE SUGAR AND ALCOHOL INDUSTRY}

Candidate: MARIO CELSO FERNANDES LACÔRTE Adviser : Prof. Max Lazaro V. Bose

\section{SUPMARY}

The use of dry yeast or concentrate of vinasse, associated to auto hydrolysed sugar cane (BAH) in rations for feedlot, was compared to BAH rations containing cotton seed meal as a protein source. A feedlot trial (initial body weight $=316 \mathrm{~kg}$ ) was carried out during a 122 day period. The rations, formulated to provide $1,0 \mathrm{~kg}$ of weight gain per day, were composed by $50 \%$ of $\mathrm{BAH}$ and $12,7 \%$ of the protein source (cotton seed meal or concentrate of vinasse or yeast) $17,8 \%$ of corn and $12,5 \%$ of sugar cane stalks as roughage com plement. The mean weight gain was 843,989 and $580 \mathrm{~g} /$ animalday for the rations containing cotton seed meal, yeast and concentrate of vinasse, respectively. The rations containing yeast and cotton seed meal have provided higher weighing gains $(P<0,01)$ when compared to the ration containing con 
centrate of vinasse. No significant differences were observed between the rations containing yeast and cotton seed meal, even at $5:$ level by the Tukey test. The results have shown that the cotton seed meal may be completely substituted by the dry yeast in complete rations of feedlot containing auto hydrolysed sugar cane bagasse (BAH). However, one should consider the economic aspects of such substitution. 


\section{INTRODUÇÃO}

o bagaço de cana-de-açúcar, maior residuo em volume da produção de açúcar e álcool, era até bem pouco tempo descartado e em alguns casos até mesmo considerado im pecilho para o bom funcionamento das unidades industriais de usinas e destilarias de açūcar e ạ̉ cool.

Recentemente, entretanto, pesquisas têm se desenvolvido na tentativa de viabilizar o uso do excedente de bagaço como fonte básica para geraçāo de energia e como alimento volumoso para ruminantes, além de outros usos ainda restritos, como produção de aglomerados para substitui ção de madeira e produção de compostos orgânicos para aduba ção.

No momento atual, a opção que mais tem atraí do os empresários do setor é a produção de alimentos atravês da auto-hidrólise do bagaço de cana, que permite seu u so como componente volumoso de rações completas para confi namento dè bovinos em níveis de atê $60 \%$ da Matéria Seca (M. S.), com ganhos de peso diârio na faixa de $1,0 \mathrm{~kg} / \mathrm{cab}$. dia (BURGI, 1985). Estima-se que na safra 1987 mais de 20.000 bovinos terão sido confinados utilizando esse resíduo como 
prinçipal volumoso. Em 1986, foram confinadas mais de 5.000 cabeças com resultados econômicos de ganho de peso comprovados (PLANO CONSULTORIA AGRCPECUARIA, 1986).

Outras duas fontes potenciais de produção de alimentos para ruminantes, nas usinas e destilarias, de acordo com tếcnicos do setor, são a levedura e a vinhaça con centrada, e jâa existem hoje algumas usinas e destilarias produzindo concentrados secos a partir destes dois resíduos. 0 uso desses dois concentrados proteicos pá ra fins de alimentação animal tem sido estudado por diversos pesquisadores, e alguns deles jâ são comercializados por algumas usinas e destilarias, tais como a. Usina Nova Améri ca (Assis-SP) e a Destilaria Univalem (Valparaiso-SP).

o objetivo do presente trabalho $\vec{e}$ verificar a viabilidade do uso desses dois concentrados (levedura e concentrado de vinhaça) juntamente com o bagaço hidrolisado, em substituição a fontes proteicas tradicionais (farelo de algodão), sobre o desempenho de bovinos confinados, o que permitiria, sem dưvida, maior autonomia das indústrias de a çücar e ảlcool na condução de confinamentos anexos, uma vez que dependeriam de poucos insumos externos. 


\section{REVISÃO DE LITERATURA}

\subsection{Bagacio AUTO-HidRoLI SAdO}

A grande quantidade de sobras de bagaço de cana-de-açücar já vem estimulando há algum tempo pesquisado res a utilizâ-1o como volumoso em rações, principalmente pa ra ruminantes.

A baixa densidade e a baixa digestibilidade do bagaço têm sido fatores limitantes em sua utilização, con forme indicam os resultados obtidos por CAMPOS et alji (1977) em ensaio de consumo e digestibilidade, os quais encontraram um coeficiente de digestibilidade aparente de $26,6 \%$ pa ra a M.S. Nesse mesmo trabalho, o bagaço apresentou $0,2 \%$ de proteína digestível e $1.743 \mathrm{kcal} / \mathrm{kg}$ de energia digestivel, e o conteúdo estimado de Nutrientes Digestiveis Totais (NDT) foi de $39,6 \%$ contra $65,1 \%$ para a raspa de mandioca.

o uso de elevadas proporçōes de bagaço in na tura, como volumoso em rações, prejudica o desempenho de bo vinos confinados. PACOLA et alii (1977), utilizando rações com $57 \%$ de bagaço de cana-de-açúcar em comparação com raçôes de igual proporção de feno de capim jaraguả (Hyparrhenia ru 
6a), verificaram redução significativa de $226 \mathrm{~g} / \mathrm{dia}$ no ganho de peso dos animais alimentados com bagaço (ganhos de 0,960 e $0,870 \mathrm{~kg}$ por cabeça por dia para os 2 tratamentos com feno de jaraguá e de 0,720 e $0 ; 650 \mathrm{~kg}$ por cabeça "por dia para 2 tratamentos com bagaço de cana).

Em outro experimento com vacas de leite (RAN DEL, 1966), ao utilịzar rações completas com proporções ain da menores de bagaço de cana, $15 \%$ da M.S. e $85 \%$ de concentrados, notou-se acréscimo na produção de leite, de sổidos totais e gordura. Observarain-se, ainda, vantagens econômicas significativas para a ração com bagaço quando compara das a dietas com silagem e concentrado e com acesso a pasta gem, embora as vacas tenham consumido o dobro da quantidade de concentrados.

Em proporçōes pequenas o bagaço de cana in natura pode ser utilizado com maior eficiencia, conforme de monstram os resultados de RANDEL (1970-a), que, trabalhando com vacas produzindo $20-25 \mathrm{~kg}$ de 1eite/dia, não observou re dução na produção de leite quando utilizou rações contendo $22,5 \%$ de bagaço in natura na M.S. . O mesmo pode ser observa do no traba1ho de ROMAN-PONCE et alii (1975), que utilizando 26 vacas em lactação produzindo em média $15 \mathrm{~kg}$ de leite/ dia, conseguiram empregar bagaço de cana-de-açúcar peletiza do na faixa de 30 a $40 \%$ da M.S. das rações sem prejuízo na produçà̃o e com maiores teores de gordura no leite nas rações 
contendo $40 \%$ do bagaço na M.S..

o mesmo autor (RANDEL, 1970-b), em um experi mento de ganho de peso com bezerros das raças holandesa e parda suiça, de 212 a 278 dias de idade e peso entre 72,9 e $152,55 \mathrm{~kg}$, obteve ganhos diários de atë $1,175 \mathrm{~kg}$ com rações contendo de 20 a $30 \%$ de bagaço na. M.S. .

O efeito sobre o crescimento e reprodução de 40 novilhas mestiças (gir-holandesas com idade entre $180 \mathrm{e}$ 250 dias, pesando de 65 a $114 \mathrm{~kg}$ ) consumindo rações conten do bagaço de cana, foi estudado por JOSHI e RANGNEKAR (1979). Os autores não observaram diferença entre os ganhos de peso diärios de novilhas alimentadas com raçäo completa contendo $20 \%$ de bagaço de cana e novilhas mantidas com concentrados, palha de sorgo e pastagens, situando-se o ganho de peso em $0,480 \mathrm{~kg} / \mathrm{cab}$. dia. O consumo por quilograma de unidade de ganho foi maior para as rações com bagaço $(11,1 \mathrm{~kg})$ do que para o controle $(10,7 \mathrm{~kg})$. O custo da alimentação foi menor na ração que utilizou bagaço, sem afetar o crescimento. quan to aos aspectos reprodutivos, não se observou diferença quanto à idade da $1^{\text {a }}$ cria e número de inseminaçöes requeridas por concepção.

Ao substituir feno moído de capim colonião (Panicum maximum) (50\% de M.S.) por uma mistura de bagaço de cana (20\%) e torta de filtro (30\% da M.S. da ração) em rações completas, fornecidas a 36 mestiços piamonteses $x$ ze 
bus, LEME et alii (1982) observaram reduçāo de 21 e $24 \%$ de consumo e ganho de peso dos animais, respectivamente.

Como se nota, o uso do bagaço in natura em formulação de rações para ruminantes é bastante limitado, surgindo, portanto, a necessidade de um tratamento prëvio, visando elevar a digestibilidade e, consequentemente, o va lor nutritivo.

Existem hoje vârios processos para o tratamento de residuos de cultura altamente lignificados, visan do elevar seu valor nutritivo. Em extensa revisão sobre o assunto, JACKSON (1978) subdividiu os mëtodos de tratamen tos basicamente em 3 grandes grupos: Tratamentos Químicos, Biológicos e Físicos. Neste ủltimo se enquadra o tratamento sob pressão de vapor-auto-hidrôlise. Dentre esses processos conhecidos, capazes de promover uma alteração positiva con siderâvel sobre a digestibilidade do bagaço de cana, o mais utilizado hoje no país, por usinas e destilarias, é o de au to-hidrólise (que utiliza pressão de vapor), principalmente pela disponibilidade de vapor, facilidade de operação e, con sequentemente, custos reduzidos de processamento. Esse processo vem sendo estudado com diversos resíduos lignoceluló sicos, desde que foi descrito em 1931 por Mason (MACHADO, 1982) e consiste basicamente em se submeter o material lig nocelulósico a elevadas pressões e temperaturas durante tem po determinado e, em seguida, promover uma rảpida descompres 
são (MACHADO, 1982). Este tratamento promove alteração na composição das fibras, com consequente aumento da digestibi lidade do bagaço de cana. Os trabalhos com auto-hidrölise se iniciaram no Brasil na Destilaria Alcídia, em 1981, e fo ram intensamente estudados por BURGI (1985), que determinou os nỉvis de processamento no que diz respeito a pressão e tempo de tratamento, para caso específico daquela destilaria. Sabe-se que a digestibilidade in vitro do material tra tado aumenta com o aumento do tempo de tratamento atë um ponto mâximo e depois decresce, para uma mesma pressão adotada. Além disso, tantos maiores serão os aumentos de diges tibilidade in vitro obtidos, quanto maiores foram as pressões de trabalho. Entretanto, nesse caso os patamares para um bom tratamento se estreitam, o que aumenta a margem de erro durante a operação, conforme indica a figura 1, extraí da do trabalho de Taylor e Esdale (sem data), citado por BURGI (1985).

Outros trabalhos utilizando bagaço de cana, em que as pressões e os tempos de tratamento tambëm variaram, indicam diferentes resultados sobre o incremento da di gestibilidade, conforme mostra a Tabela 1 , extraída do tra balho de BURGI (1985). 
.8.

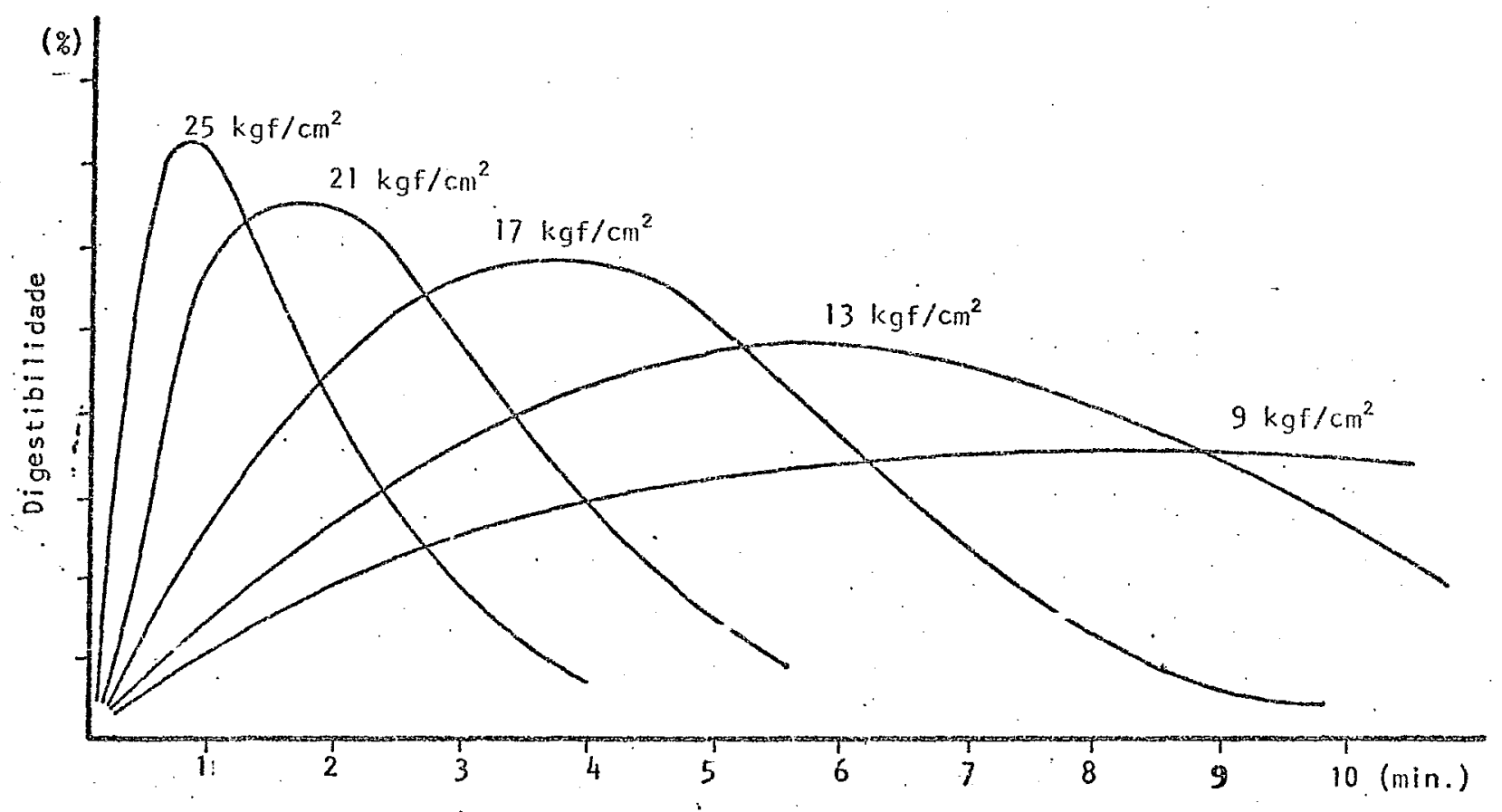

Figura 1 - Efeito da pressão e tempo de tratamento sobre a digestibili dade do bagaço de cana.

FONTE: TAYLOR e ESDALE (s/data) e BURGI. (1985) 
Tabela 1 - Resultados de tratamento com pressäo de vapor sobre a diges tibilidade in vitro da MS (DIVMS) do bagaço de cana.

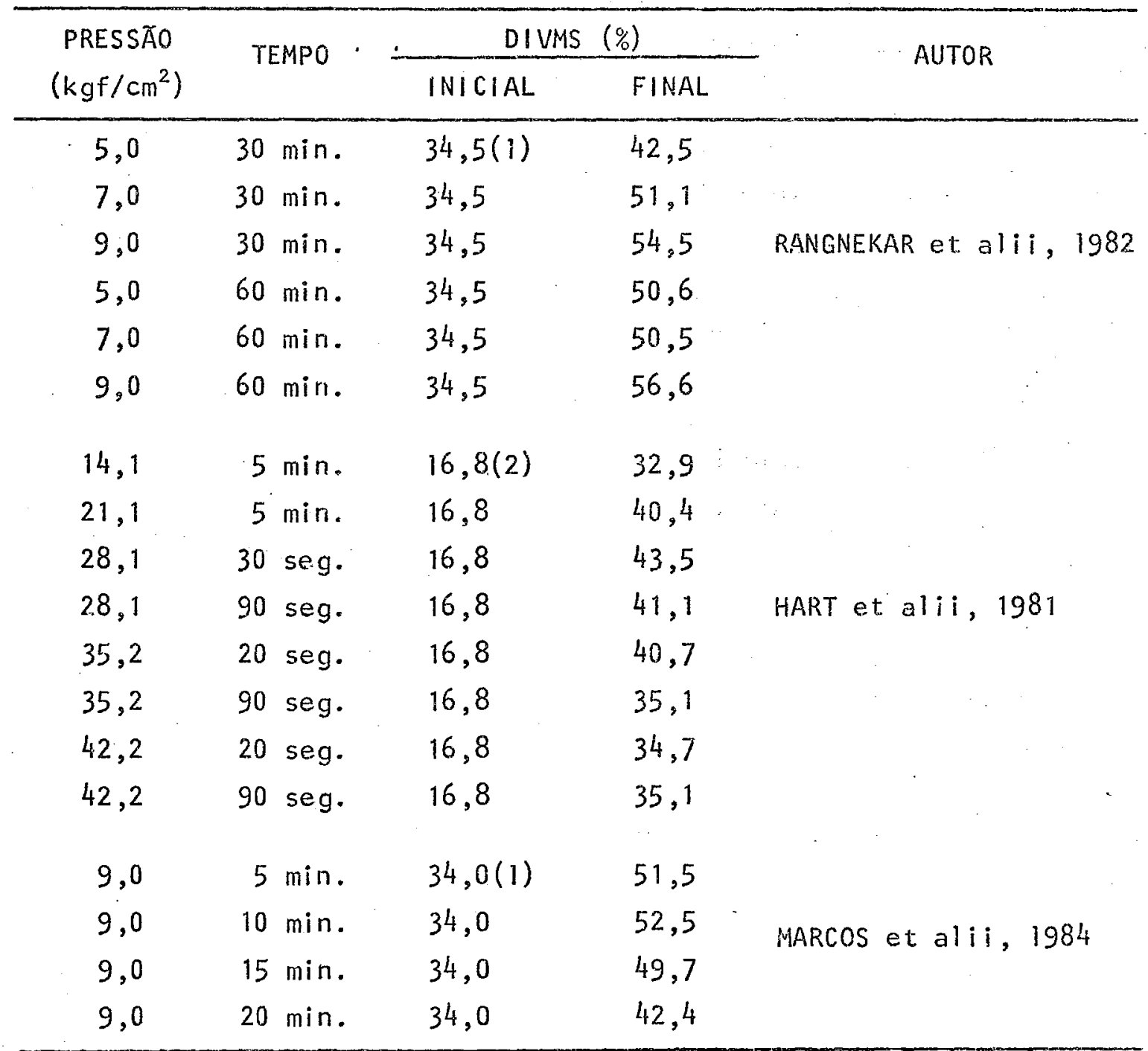

(1) Método de Tilley-Terry.

(2) Método de Guggolz, modificado por Hart - determinação dos solïveis após digestão com celulose de Trichoderma viride por 16 horas.

MS = Matéria Seca .

Com base em anālises bromatológịcas do baga ço in natura e do bagaço auto-hidrolisado, pode-se identifi 
car algumas alterações bäsicas entre os dois alimentos, cọ mo o aumento da fração extrato etéreo no bagaço auto- hidró lisado observado por MARCOS et alii (1984), que utilizando pressão de $9 \mathrm{kgf} / \mathrm{cm}^{2}$, durante $0,5,15$ e 20 minutos, verifi caram teores de extrato etéreo de $2,5,4,4,8,9$ e $11,5 \%$ res pectivamente. A alteração nos percentuais de extrato etéreo foi atribuîda à extração de compostos não lipídicos, provavelmente produtos fenólicos decorrentes da degradaçäo de lignina.

Com base nas recomendações de JACKSON (1978), de que a avaliação do efeito de tratamentos que visam me tho rar o valor nutritivo de volumosos grosseiros deve ser rea lizada através da comparação dos resultados da digestibilidade in vitro dos materiais in natura e tratado, BURGI (1985) realizou 24 tratamentos com diferentes combinações de pressão e tempo, visando estabelecer as melhores condiçóes do processo na Destilaria Alcídia. A pressão variou de 8 a 19 $\mathrm{kgf} / \mathrm{cm}^{2}$, e o tempo de 2 a 14 minutos, conforme mostra a tabela 2 .

Confirmou-se, pelos resultados, que quanto mais alta a pressāo, menor é o tempo necessārio para o tra tamento e mais elevados são os valores de digestibilidade $\underline{a}$ tingidos (BURGI, 1985), conforme ilustra a Figura 2. 
Tabela 2 - Digestibilidade verdadeira in vitro da MS (DIVMS) do bagaço auto-hidrolisado en função da pressão e do tempo de tratamen to.

\begin{tabular}{|c|c|c|c|}
\hline $\begin{array}{c}\text { AMOSTRA } \\
\left(\mathrm{kgf} / \mathrm{cm}^{2}\right) /(\min .)\end{array}$ & $\mathrm{pH}$ & $\begin{array}{l}\text { MS } \\
(\%)\end{array}$ & $\begin{array}{c}\text { DIVMS } \\
(\%)\end{array}$ \\
\hline $\begin{array}{c}19 / 02 \\
17 / 14 \\
17 / 12 \\
17 / 10 \\
17 / 08 \\
17 / 06 \\
17 / 04 \\
17 / 02 \\
14 / 14 \\
14 / 10 \\
14 / 06 \\
14 / 04 \\
14 / 02 \\
11 / 14 \\
11 / 10 \\
11 / 04 \\
11 / 02 \\
08 / 14 \\
08 / 10 \\
08 / 06 \\
08 / 04 \\
08 / 02 \\
00 / 00 \\
\text { Padrão Bagaço } \\
\text { Padrão Napier } \\
\text { Bagacil } 17 \text { ho } 17 / 5\end{array}$ & $\begin{array}{l}3,3 \\
\frac{3,2}{3,3} \\
\frac{3,4}{3,7} \\
\frac{3,4}{3,6} \\
\frac{3}{3,5} \\
\frac{3,8}{5,5} \\
\frac{3}{3,7}\end{array}$ & $\begin{array}{l}38,58 \\
29,76 \\
32,08 \\
36,26 \\
40,96 \\
36,97 \\
40,08 \\
39,56 \\
36,90 \\
41,26 \\
41,22 \\
44,81 \\
44,97 \\
36,05 \\
39,39 \\
42,22 \\
46,07 \\
36,69 \\
39,54 \\
37,67 \\
43,21 \\
42,57 \\
44,05 \\
48,31 \\
28,83\end{array}$ & $\begin{array}{l}77,47 \\
70,88 \\
71,64 \\
73,67 \\
73,01 \\
77,61 \\
73,02 \\
68,71 \\
68,94 \\
70,57 \\
66,10 \\
59,79 \\
57,00 \\
75,59 \\
73,14 \\
61,02 \\
58,27 \\
71,64 \\
63,43 \\
59,17 \\
56,92 \\
54,91 \\
46,41 \\
47,85 \\
77,85 \\
64,24\end{array}$ \\
\hline
\end{tabular}

Estimativa da digestibilidade verdadeira, segundo método de Tilley- Ter ry modificado por Van SOEST (1982).

BURGI (1985)

MS = Matēria Seca 


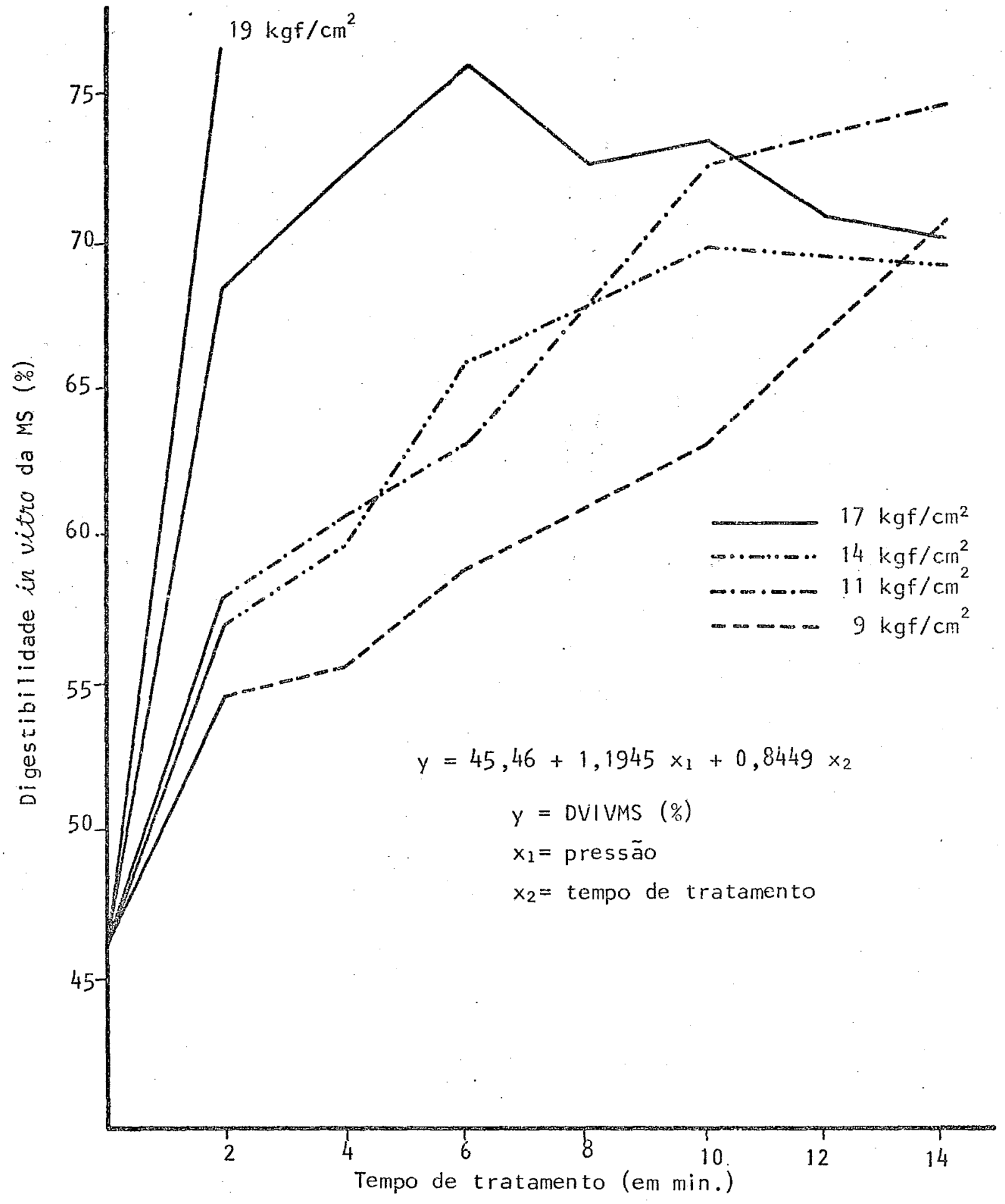

Figura 2 - Digestibilidade verdadeira in vitro da matéria seca (DIVMS) do bagaço hidrolisado, em função da pressão e tempo de trata mento.

FONTE: BURGI (1985) 
Apös a padronização do tratamento na Destila ria Alcídia, com base nos resultados de digestibilidade a $17 \mathrm{kgf} / \mathrm{cm}^{2}$ de pressão e tempo de 5 minutos, realizaram- se diversos tratamentos sob essas condiçôes e foram tomadas a mostras para análises bromatolögicas para se verificar a re petibilidade dos tratamentos (BURGI, 1985).

Com base nos resultados mêdios dessas anälises (Tabeḷa 3), o autor observou que após o tratamento ocor re diminuição no teor de Fibra em Detergente Neutro (NDF) devido, provavelmente, ao desaparecimento de hemicelulose, ligeiro acréscimo no teor de extrato etéreo, manutenção dos níveis de celulose, lignina e proteína, redução da fibra bru ta e incremento no teor de extrativo não nitrogenado. Ocorre, ainda, a diminuição no teor de matéria seca, aumento de acidez do material tratado e incremento de $84 \%$ na digestibi lidade in vitro da M.S., com relação ao bagaço in natura (BURGI, 1985).

Os efeitos da adição de soluções de amônia, urêia ou soda, ao material lignocelulósico antes de submetê-10 ao tratamento a vapor, foram estudados por HART et a1ii (1981). Os aditivos nitrogenados não tiveram efeito so bre a digestibilidade in vitro das amostras tratadas. A re tenção de nitrogênio adicionado foi quase total atê o nível de $1,5 \%$ de uréia sobre a matéria seca. Alêm desse valor, a retenção do excesso de nitrogênio foi pequena. A adição de 
soda aos níveis de $2 \%$ e $4 \%$ da matéria seca promoveu incremento de $64 \%$ da digestibilidade in vitro contra $47 \%$ de in cremento no material tratado só com vapor; sendo esse incre mento mais expressivo para casca de arroz que para o bagaço de cana. As pressões de tratamento nesses ensaios variaram de 7 a $42,2 \mathrm{kgf} / \mathrm{cm}^{2}$.

Tabela 3 - Resultados médios de análises bromatológicas do bagaço auto-hidrolisado (BAH) $17 / 5$ e do bagaço in natura.

\begin{tabular}{|c|c|c|}
\hline DETERMINAÇÃOO & $\begin{array}{l}\text { BAGAÇO } \\
\text { IN NATURA }\end{array}$ & $\begin{array}{c}\text { BAGAÇO } \\
\text { AUTO-H! DROLISADO }\end{array}$ \\
\hline Matéria seca $(\%)$ & 48,31 & 40,32 \\
\hline \multicolumn{3}{|l|}{ - em g/100 g de matéria seca } \\
\hline $\begin{array}{l}\text { Proteína bruta } \\
\text { Fibra bruta } \\
\text { Extrato etēreo } \\
\text { Matēria mineral } \\
\text { Extrativo não ni trogenado } \\
\text { Fibra em detergente neutro (NDF) } \\
\text { Fibra em detergente äcido (ADF) } \\
\text { Celulose }\end{array}$ & $\begin{array}{r}1,86 \\
45,09 \\
2,26 \\
2,73 \\
48,06 \\
85,24 \\
62,33 \\
44,69\end{array}$ & $\begin{array}{r}1,67 \\
34,45 \\
4,86 \\
4,77 \\
54,25 \\
58,16 \\
62,65 \\
43,99\end{array}$ \\
\hline $\begin{array}{l}\text { Hemicelulose } \\
\text { Lianina em detergente äcido }\end{array}$ & $\begin{array}{l}22,91 \\
14,89\end{array}$ & $\overline{15,06}$ \\
\hline $\begin{array}{ll}\mathrm{Ca} & \end{array}$ & n.d. & 0,12 \\
\hline $\mathrm{P}$ & n.d. & 0,02 \\
\hline K & n.d. & 0,16 \\
\hline DVIVMS (1) & 33,31 & 64,82 \\
\hline
\end{tabular}

MS = matéria seca

DIVMS = digestibilidade in vitro da MS

(1) Estimativa da digestibilidade aparente da MS, calculada subtraindo-se 12,9 pontos percentuais da DVIVMS mëdia obtida em diversas a mostras de BAH $17 / 5$ e bagaço in natura.

Fonte: BURGI (1985) 
Testes de avaliação do bagaço de cana e outros volumosos grosseiros tratados por pressão de vapor já foram realizados com animais.

PATE (1982), trabalhando com novilhos de 275 $\mathrm{kg}$ de Peso Vivo, comparou o consumo de raçōes completas con tendo 56\% de Bagaço Hidrolisado (BAH) na matéria seca com rações contendo $56 \%$ de bagaço in natura (B) na MS. A digestibilidade da Fibra Bruta (FB), Fibra em Detergente Neutro (FDN), Fibra em Detergente Åcido (FDA) e Celulose foi, res pectivamente, de $44,31,67 \in 46 \%$ majs alta na ração conten do $B A H$ que na ração contendo $B$. A digestibilidade da protei na Bruta (PB) foi $55 \%$ mais alta em $B$. Nesse experimento o bagaço havia sido tratado a $19,4 \mathrm{kgf} / \mathrm{cm}^{2}$ por un tempo de 4,3 minutos.

Em teste de consumo, utilizando os mesmos a nimais e as mesmas condições de tratamento para o bagaço, PA TE (1982) observou que com niveis inferiores de BAH (32\% da Matëria Seca) o consumo da ração foi maior. Em 20 dias de fornecimento obteve consumo de $6,8 \mathrm{~kg}$ de MS por cabeça por dia em rações completas com $32 \%$ de BAH e consumo de $2,8 \mathrm{~kg}$ de MS por cabeça por dia em raçōes com $56^{\circ}$ de BAH.

Em outro trabalho com bagaço tratado a 20,4 $\mathrm{kgf} / \mathrm{cm}^{2}$, durante 2 minutos, PATE (1982) utilizou novilhos alimentados com uma dieta contendo $0,14,30$ e $46 \%$ de BAH na MS. Os ganhos mëdios de peso dos novilhos com essas die 
tas foram respectivamente 1,$10 ; 1,23 ; 1,40$ e $0,88 \mathrm{~kg}$ por ca beça por dia, correspondente aos consumos de 10,21; 10,93; 11,45 e $10,42 \mathrm{~kg}$ de MS por cabeça.

CAMPBELL et alii (1973), trabalhando com car neiros, compararam 3 dietas contendo $40 \%$ na MS de bagaço tratado, BAH tratado e peletizado e não tratado e peletizado. Os resultados para a digestibilidade da matëria orgâni ca foram de $72,0 \%$ para o $\mathrm{BAH}, 67,5 \%$ para o $\mathrm{BAH}$ peletizado e $61,4 \%$ para o bagaço natura1 e correspondentes consumos de M.S. de 568,$6 ; 571,9$ e $381,7 \mathrm{~g} / \mathrm{cab}$,dia.

Após a padronização do tratamento do $\mathrm{BAH}$ em $17 \mathrm{kgf} / \mathrm{cm}^{2}$ durante 5 minutos (BAH $17 / 5$ ), BURGI (1985) reali zou 2 testes de consumo com bovinos de corte. No primeiro foi determinada uma regressão significativa entre a propor ção de BAH $17 / 5$ na dieta e consumo voluntärio de Matẻria Se ca (Figura 3). No segundo, o consumo de rações com elevada proporção de BAH $17 / 5$ foi satisfatório, independentemente da adição de melaço como palatabilizante na ração $74 \mathrm{M}$, con forme indica a Tabela 4 . 


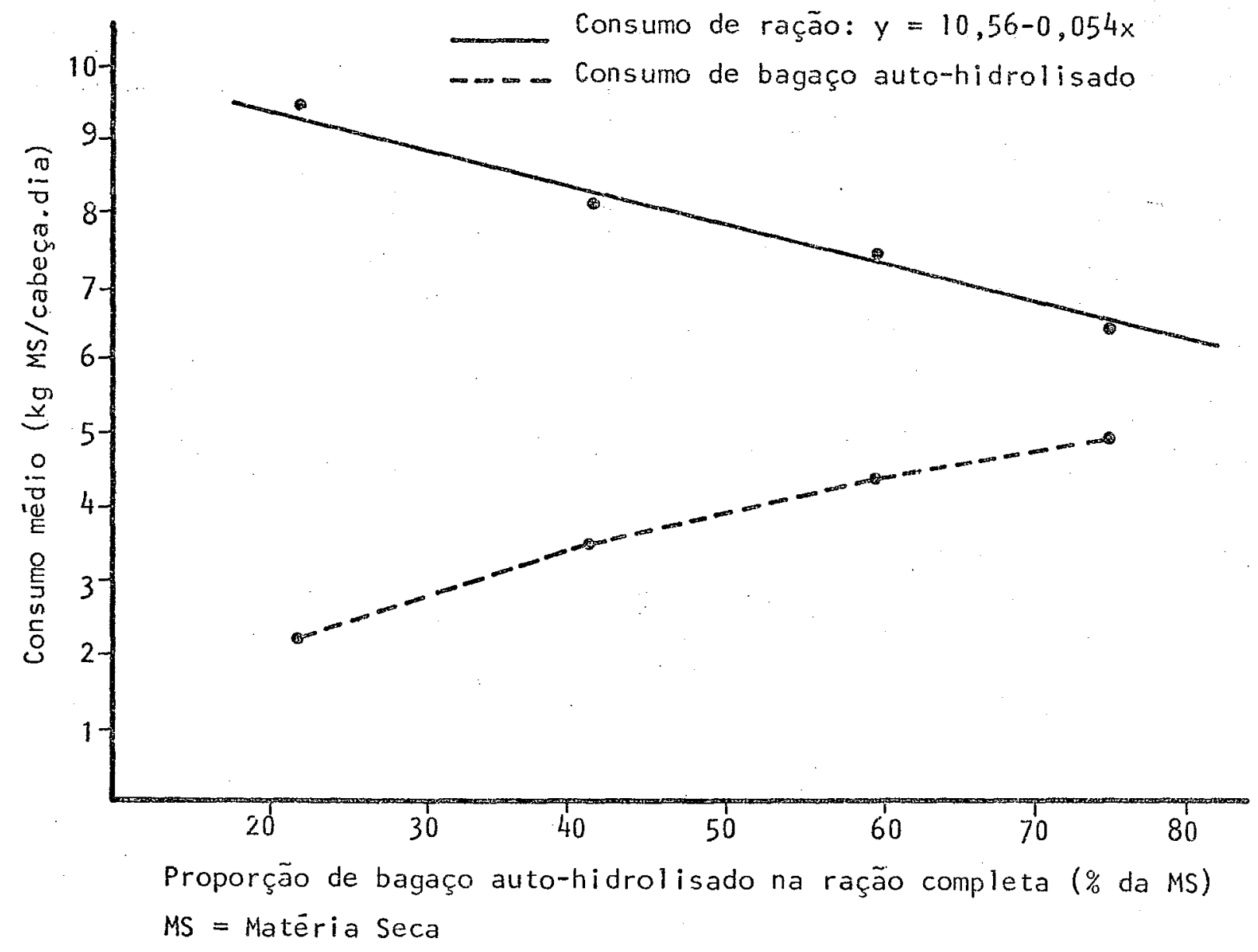

Figura 3 - Consumo médio de mistura de ração, em função da proporção de bagaço auto-hidrolisado (BAH) $17 / 5$ na ração completa.

FONTE : BURGI (1985) 
Tabela 4 - Consumo de matéria seca de bovinos alimentados com rações completas à base de bagaço auto-hidrolisado com $17 \mathrm{kgf} / \mathrm{cm}^{2}$ de pressão durante 5 minutos (BAH - 17/5).

\begin{tabular}{|c|c|c|c|c|}
\hline \multirow{2}{*}{ TRATAMENTO } & \multicolumn{2}{|c|}{ CONSUMO } & \multirow{2}{*}{$\begin{array}{l}\text { PV } \\
\text { MEDIO } \\
(\mathrm{kg})\end{array}$} & \multirow{2}{*}{$\begin{array}{c}\text { CONSUMO } \\
\text { PROPORCIONAL } \\
(\mathrm{kg} \mathrm{MS} / 100 \mathrm{~kg} \text { PV dia }\end{array}$} \\
\hline & $\mathrm{kg}$ Mo/cab.dia & $\mathrm{kg} \mathrm{MS} / \mathrm{cab} \cdot \mathrm{dia}$ & & \\
\hline Ração $74 \mathrm{M}$ & 18,60 & 9,38 & $323 ; 05$ & 2,90 \\
\hline Ração 74 SM & 16,36 & 8,80 & 316,30 & 2,78 \\
\hline \multicolumn{2}{|c|}{$M=$ com me laço } & \multicolumn{3}{|c|}{$\mathrm{SM}=$ sem melaço } \\
\hline
\end{tabular}

Como os novilhos utilizados nos 2 testes foram os mesmos, verificou-se que a adaptaçāo a dietas conten do BAH em elevadas proporções é lenta, decorrendo 20 a 30 dias até a estabilização do consumo.

Após esse período, a elevada proporção de BAH $17 / 5$ ( $74 \%$ da MS) não prejudicou o consumo voluntário das ra ções completas, sendo que seu consumo nas dietas atingiu ní veis superiores a $2 \mathrm{~kg}$ MS/100 $\mathrm{kg}$ PV, quando fornecido na pro porção de $74 \%$ da matéria seca da dieta (BURGI, 1985).

Estimulado pelos bons resultados em consumo, o mesmo autor (1985) realizou um experimento de ganho de pe so com bovinos confinados com 4 rações contendo 40, 50; e $60 \%$ de BAH $17 / 5$ (17 kgf/ $\mathrm{cm}^{2}$ durante 5 minutos) na MS e $60 \%$ de bagaço in natura (B) na MS, cana-de-açúcar picada e con centrado. Todas as rações tinham as mesmas proporções do 
mesmo concentrado proteico (concentrado comercial com $32 \%$ de PB na MS - Produleite) e volumoso, sendo o total de volu moso completado com a cana.

Os consumos de MS verificados foram de 11,17 11,$36 ; 11,77$ e $7,19 \mathrm{~kg}$ após a estabilização e de $9 ; 92 ; 10,00$; 10,13 e $6,71 \mathrm{~kg}$ durante o período de comparação, respectiva mente para as rações com 40,50 e $60 \%$ de BAH e $60 \%$ de B. Dú rante o período de comparação ( $72 \cdot$ dias), os ganhos médios de peso por boj foram de 0,$960 ; 0,816 ; 0,872$ e $0,699 \mathrm{~kg} /$ dia e após a estabilização (últimos 42 dias do experimento) dé 0,$981 ; 0,931 ; 1,160$ e $0,613 \mathrm{~kg} / \mathrm{dia}$ respectivamente para os tratamentos com $40,50,60 \%$ de BAH e $60 \%$ de B de Matéria Se ca. BURGI (1985) concluiu que, sob condições específicas de tratamento, o BAH pode ser utilizado na substituição de cana picada, em rações completas de confinamento com elevada proporção de volumoso, sem prejuízo de consumo, ganho de pe so e conversão alimentar.

\subsection{Concentrado de Vinhaça (Levedura de Vinhaça)}

A vinhaça, residuo final da produção de á1cool, foi e ainda é o motivo de maior preocupação no que diz respeito à poluição ambiental, quando se considera a possivel expansão da indústria alcooleira no país. 
Esse residuo, altamente poluente, $\vec{e}$ gerado na proporção de 12 a 141 por litro de âlcool produzido (CAMH I , 1979) .

Com relaçāo às substâncias presentes na vi- nu nhaça, URBAN (1976) afirmou que três quartos são de composi ção orgânica, sendo o restante composto de sais minerais.

Várias alternativas de utilização da vinhá ça, cuja composição média se encontra na Tabela 5 : (CAMHI, 1979), vem sendo estudadas.

Seu uso agrícola, retornando à lavoura, viảvel sob certas condiçōes, e jä foi estudado por diversos pesquisadores (GLÓRIA et alii, 1972 e 1973; GLORIA, 1975), sendo empregado hoje em larga escala por usinas e destilarias.

A fermentação do vinhoto, visando a produção de proteina através da atividade biológica aeróbica do leve do Torula utilis ou outras espécies microbianas, é mais uma alternativa para sua utilização. Entretanto, para fermentação aeróbica, o vinhoto é normalmente deficiente em fosfato e nitrogênio, devendo ser suplementado com sais de amônia e fósforo (CAMHI, 1979). 
Tabela 5 - Composição quîmica da vinhaça de cana em sölidos totais e orgânicos e em elementos minerais.

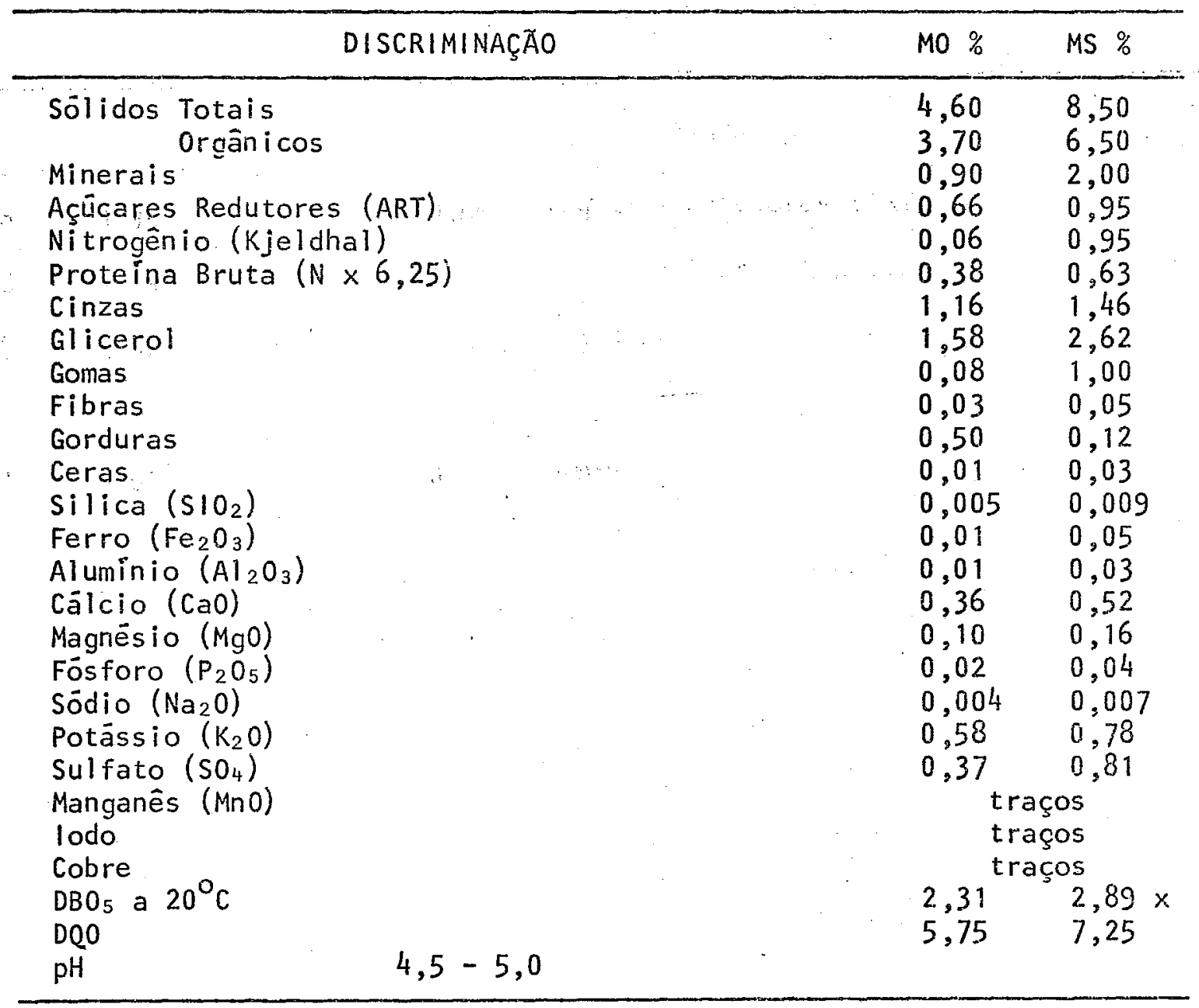

FONTE: INSTITUTO NACIONAL DE TECNOLOGIA (CAMHI, 1979).

MO = Matēria Original $\quad D B O=$ Demanda Biolögica de Oxigênio

MS = Matëria Seca DQO = Demanda Química de Oxigênio

ANGELIS (1979) promoveu o desenvolvimento de culturas puras de leveduras e culturas associadas, empregan do vinhaça suplementada com diferentes produtos. As levedu ras foram Candida utilis, Rhodotorula glutinis, Torula uti- 
lis e Candida lipolytica em 9 meios diferentes, todos contendo vinhaça. Os resultados indicam que ha aumento da bio massa quando se empregam culturas mistas, com produçōes superiores a $5 \mathrm{~g} / 1$ itro de massa, o que indica ser possivel a produçāo de proteína microbiana em meio de vinhaça. Hã., con tudo, necessidade de mais estudos sobre as suplementações re que ridas.

Já existem em outros países produção industrial de biomassa fúngica, como é o caso,da fäbrica de PE NICK and FORD (IOWA-USA), que trabalhando atualmente em re gime contínuo, com capacidade de reciclagem de 10 milhões de litros de ägua residuais do processamento de milho, con segue reduções de 90 a $95:$ na demanda bioquímica de oxigênio (DBO), diminuindo assim sensivelmente a carga poluidora com produçāo de proteína (ARAUJo et alii, 1976).

Indüstrias processadoras de café na Guatema1a, utilizando as äguas residuais, tền conseguido reduções de 70 a $80 \%$ na $D B O$, com produção de atê $4 \mathrm{~g}$ de massa füngi ca por 1itro (base seca) com $46^{\circ}$ de proteína (ARAUJo et alii, 1976).

As pesquisas com produção de massa fúngica no Brasil, segundo ARAUJO et alii (1976), indicam como fungos mais eficientes o Aspergillus arizae ATCC, O Trichoderma viride Sb1s9 e o Trichoderma viride DRI, atingindo-se, em 72 horas, reduções de $\mathrm{DBO}$ de até $83 \%$, com produção de $17,2 \mathrm{~g}$ 
de biomassa seca por litro, utilizando-se vinhoto esterili zado. A proteîna bruta na biomassa oscilou entre 35 e $50 \%$, sendo que maior porcentagem de proteina correspondia a menor produçäo de biomassa, ou seja; o rendimento em gramas de proteina não apresentou variação tão ampla.

A biomassa füngica obtida no trabalho desen volvido por ARAUJO et alii (1976), no INT (Instituto Nacional de Tecnologia) tem a composição química apresentada na Tabela 6 .

A massa fúngica da análise referida foi tes tada com pintos, em trabalho experimental de $2 \pi$ dias, com bons resultados. Os autores do trabalho consideram viável e conomicamente a produção de massa füngica, que compete posi tivamente com o farelo de soja (ARAUJO et alii, 1976), quan do aquela é produzida próximo a regiōes de criação de animais.

Outra utilização possível em estudo para o vinhoto é a produção de metano através de fermentação anaeröbica (PFEFFER, 1976; LENNART, 1976), mediante condições específicas.

0 principal objetivo dessa parte de revisão, entretanto, é o uso da vinhaça concentrada na alimentação $\underline{\text { a }}$ nimal, uma vez que este foi um dos suplementos proteicos utilizados no presente trabalho. 
Tabela 6 - Anälise química bromatológica de biomassa fúngica.

\begin{tabular}{|c|c|}
\hline DISCRIMINAÇÃO & VALOR $(\%)$ \\
\hline $\begin{array}{l}\text { Umidade } \\
\text { Proteína bruta }(\mathrm{N} \times 6,25) \\
\text { Gorduras } \\
\text { Fibra bruta } \\
\text { Cinzas } \\
\text { Gomas } \\
\text { Hidratos de carbono } \\
\text { Cálcio } \\
\text { Fösforo } \\
\text { Potässio } \\
\text { Södio } \\
\text { Magnēsio } \\
\text { Acidos nucleicos }\end{array}$ & $\begin{array}{r}4,10 \\
38,59 \\
3,60 \\
4,20 \\
15,60 \\
3,20 \\
25,00 \\
0,48 \\
1,40 \\
0,21 \\
0,01 \\
0,07 \\
8,01\end{array}$ \\
\hline
\end{tabular}

COMPOSIÇÃO EM AMINOACIDOS ESSENCIAIS, EXPRESSA EM g DE AMINOACIDO POR $100 \mathrm{~g}$ DE PROTETNA NA BIOMASSA $\left({ }^{*}\right)$

$\begin{array}{lr}\text { Treonina } & 13,41 \\ \text { Glicina } & 5,38 \\ \text { Valina } & 8,57 \\ \text { Metionina } & 1,18 \\ \text { Isoleucina } & 5,90 \\ \text { Leucina } & 7,63 \\ \text { Fenilalanina } & 4,61 \\ \text { Lisina } & 6,77 \\ \text { Histidina } & 2,51 \\ \text { Arginina } & 4,89\end{array}$

(*) Anālise realizada pelo Laboratörio de Proteínas do Instituto Nacio nal de Tecnologia (1976).

FONTE: ARAUJO et alii (1976).

URBAN (1976) apresentou 3 motivos principais para justificar a concentraçāo da vinhaça:

$\left.1^{\circ}\right)$ Aproveitamento da sua riqueza em substân cias orgânicas e minerais.

29) Proteção dos recursos hídricos regionais 
contra poluição.

3\%) Obtenção de vinhaça concentrada, xarope estável que possui aplicação como fertilizante e componente para ração animal.

Segundo o mesmo autor, a utilizaçāo da vinha ça: concentrada em raçōes balanceadas jä é bem difundida em alguns países europeus, como substituto do melaço. A excelente palatabilidade que a vinhaça concentrada confere às rações, associada ao seu aumento no poder de aglutinação, transformou esta fonte poluidora em produto já comercializá vel na Europa, atingindo preços de até US\$ 40/ton. em 1975.

As primeiras unidades construidas para concentração de vinhaça foram fabricadas durante a $2^{a}$. Guerra Mundial, tendo sido montadas, desde então, cerca de 40 plan tas projetadas pelo engenheiro Wilhelm Vogelbush (URBAN, 1976). Embora a maioria das plantas projetadas tenha sido destinada a evaporar vinhaça de beterraba, hoje jā existem resultados positivos a partir da destilação do melaço de ca na.

0 sistema de concentração é constituído por evaporadores de quädruplo efeito (quatro evaporaçōes consecutivas).

A descrição completa do processo de concentração atê níveis de $60^{\circ}$ BRIX pode ser encontrada nos traba 1hos de URBAN (1976) e PUPO (1981). 
Após a concentração, visando-se melhores con dições de secagem, podem ser adicionadas 12 ton. de creme dé levedura a 70-75 ton. de vinhaça concentrada. Obtêm-se, des sa maneira, após a secagem pelo processo de "spray- dryer". (ventilação forçada da massa contra corrente de ar quente), um produto em pó com teor proteico de $32 \%$ da M.S. (URBAN, 1976).

Os rendimentos da vinhaça concentrada e da vinhaça concentrada seca foram determinados por URBAN (1976) e se encontram na Tabela 7. Considerando-se o funcionamento dos três tipos de destilarias em 180,200 e 250 dias por sa fra, respectivamente.

Tabela 7 - Rendimentos mëdios obtidos na produção de vinhaça concentra da.

DETERMINAÇÃO ANUAL

Números dos dias por safra 180

200

250

Alcool produzido à base $60.000 \mathrm{l} / \mathrm{dia}$

$10.800 \mathrm{~m}$

$12.000 \mathrm{~m}$

$15.000 \mathrm{~m}$

Matéria seca total em toneladas

11.368

3.764

3.751

Vinhaça concentrada $\left(60^{\circ}\right.$ Brix)

18.946

6.273

Ração animal em pō (92\% M.S.)

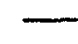

4.077

Matéria orgânica (sem considerar levedura)

9.326

3.187

3.041

$N$ (sem considerar levedura)

174

46

213

FONTE: URBAN (1976). 
Embora as informações sobre o uso da vinhaça concentrada para alimentação animal sejam positivas, são es cassos os trabalhos de pesquisa especificos sobre o uso des se componente, principalmente no estado seco, em rações ani mais, a não ser com prévio desenvolvimento de microorganis mos, como foi citado anteriormente.

A utilização de subprodutos líquidos (melaço e vinhaça) concentrados até $80^{\circ}$ Brix é recomendada por CROCHET (1967) devido a maior facilidade de manipulação e redu ção de custo de transporte. A utilização desses resíduos au mentaria ainda o consumo de rações completas, permitindo um maior aproveitamento dos volumosos, devido a presença de ví taminas, minerais, proteinas e energia (CROCHET, 1977).

Fornecendo $1,5 \mathrm{~kg}$ de vinhaça concentrada por cabeça/dia, em rações para bovinos, Rudimitriku, em 1962, ci tado por CAMPOS (1977), obteve ganhos de peso vivo da ordem de $0,940 \mathrm{~kg} / \mathrm{dia}$.

Em função do alto percentual de potässio en contrado na vinhaça, deve-se considerar os efeitos dos niveis desse mineral antes de se utilizā-la na composição das rações. NEATHERY et alii (1980) trabalharam com quatro fon tes de potássio em rações para bezerros (cloreto de potássio, acetato de potássio, carbonato de potássio e bicarbona to de potássio), com o objetivo de verificar o efeito dessas diversas fontes sobre a palatabilidade das rações, bem 
como o efeito de níveis crescentes em potâssio, sobre a poș sível toxidez das dietas (níveis de $0,77^{\circ}$ ou mais de 2,4 e $6 \%$ de potássio na dieta). As raçōes contendo 2,4 ou $6 \%$ de potássio na forma de cloreto de potássio, e as contendo 2 a $4 \%$ de K na forma de acetato, carbonato e bicarbonato de po tássio, foram menos palatâveis que a dieta controle $\left(0,77^{\circ}\right.$ de $\mathrm{K}$ ). A palatabilidade e ganho de peso decresceram com o aumento da proporção de potássio na dieta, embora níveis pou co maiores que $2 \%$ de potâssio não tenham apresentado diferenças significativas em relação ao consumo ou ganho de pe so, em comparação à testemunha, que continha apenas $0,77 \%$ de K. No mesmo trabalho foi observada uma maior excreção urinâ ria de $K$, após as primeiras semanas de ingestão de dietas com elevados teores de potássio, o que foi atribuído pelos autores a uma possivel adaptação dos animais.

WARD (1966), em uma revisão sobre o metabolismo de potássio em ruminantes, relatou que embora as ne cessidades desses animais não ultrapassem $0,5 \%$ do elemento nas rações, os mesmos estão adaptados a metabolizar quantidades bem maiores que essa, podendo ingerir $300 \mathrm{~g}$ de $\mathrm{KCl}$ num dia, sem manifestar sintomas de toxidez.

Foram observados os efeitos de substituição de melaço por vinhaça concentrada sobre o ganho de peso de novilhos (mestiços) zebu x holandês, com peso médio inicial de $278 \mathrm{~kg}$ (PUPO, 1981). Os tratamentos caracterizam-se por 
níveis crescentes $(0,0 ; 33,3 ; 66,6$ e 100,0$)$ de substituição do melaço pela vinhaça concentrada, correspondentes a $0 ; 7$, 14 e $21 \%$ ria matēria seca da raçāo. A adiçāo de vinhaça redü ziu linearmente o consumo de matéria seca e os ganhos de pé so, sem afetar a conversão alimentar nem as digestibilida des aparentes, da matēria seca e da matéria orgânica. . Com base nesses resultados o autor conclui que: 1) a substitui ção do melaço provocou declínio no desempenho dos animais; 2) atê o nível de $7 \%$ da M.S., os efeitos da vinhaça concen trada são equivalentes ao do melaço; 3) a análise conjunta dos dados indica que os efeitos depressivos da vinhaça concentrada sobre o desempenho, podem ser atribuídos a sua bai xa palatabilidade; 4) a vinhaça concentrada utilizada na en gorda de bovinos em substituição ao melaço, pode resultar em redução da quantidade de suplemento proteico; 5) aparen temente, não houve efeito tóxico da vinhaça concentrada so bre os animais; 6) deverão ser realizados novas pesquisas sobre a utilização desse resíduo em períodos experimentais mais longos.

Em outro trabalho substituindo melaço por vi nhaça concentrada, não se observaram diferenças entre as dí gestibilidades de matêria seca e proteina bruta das dietas que continham melaço, melaço e vinhaça combinados, ou somen te vinhaça concentrada. O consumo da ração contendo apenas vinhaça foi menor que o das outras duas, contendo melaço e 
melaço + vinhaça, sendo que estas proporcionaram consumos equivalentes. Concluiu-se que a viabilidade de substituição do melaço pela vinhaça concentrada em rações para bovinos é possíve1, sem redução no consumo, atë niveis de 33 a $66 \%$ Palatabilidade parece ser o fator preponderante na limitação da substituição (PIEKARSKI, 1983).

\subsection{A Levedura de Sangria}

O uso das leveduras, como alimento, já é conhecido hã muito tempo, e sua produção pode ser considerada uma atividade opcional dentro do complexo industrial produtor de açúcar e ảlcool.

Os rendimentos em função da matéria prima u tilizada foram descritos por CARNEIRO (1967), que considera a produção de levedura basicamente a partir de três fontes: o caldo de cana, o melaço de usinas e o vinhoto de destilarias, sendo as produções respectivas de 60,250 e $2.80 \mathrm{~kg}$ de levedura por tonelada, e de $35 \mathrm{~kg}$ de levedura por $4.300 \mathrm{li}$ tros de vinhoto.

o processo produtivo para a obtenção da leve dura alimentar pode ser dividido em 6 fases. (CARNEIRO, 1967): 1) a preparação da matéria prima; 2) vegetação de 1e vedura; 3) separaçāo do creme; 4) pré-concentração do cre- 
me; 5) secagem; 6) trituração e ensacamento.

Hoje em dia, existe uma linha de pensamento comum a muitos tëcnicos ligados ao setor sucroalcooleiro de que $\vec{e}$ possivel sangrar parte da levedura reciclada no processo fermentativo sem prejuízo da fermentação. Algümas em presas que jā utilizam o processo, consideram ser possível sangrar até $5 \%$ do leite de levedo.

0 esquema de produção da levedura dentro do processo normal de produção de älcool encontra-se esquemati zado na Figura 4 (MACHADO, 1983).

Considerando-se as possibilidades de extração da levedura sem prejuízo da fermentação, diversos pes quisadores passaram a realizar ensaios de alimentação com $\underline{\text { a }}$ nimais utilizando esse alimento que, assim como outras leve duras, apresenta um teor de proteína elevado conforme indica a Tabela 8 , extraída de MACHADO (1983), o qual as compa ra com o farelo de algodão.

Com relação às leveduras e ao farelo de algo dão, os teores de proteína e carboidratos são semelhantes, porém, neste ültimo, grande parte dos carboidratos estão na forma de carboidratos estruturais (MACHADO, 1983). 


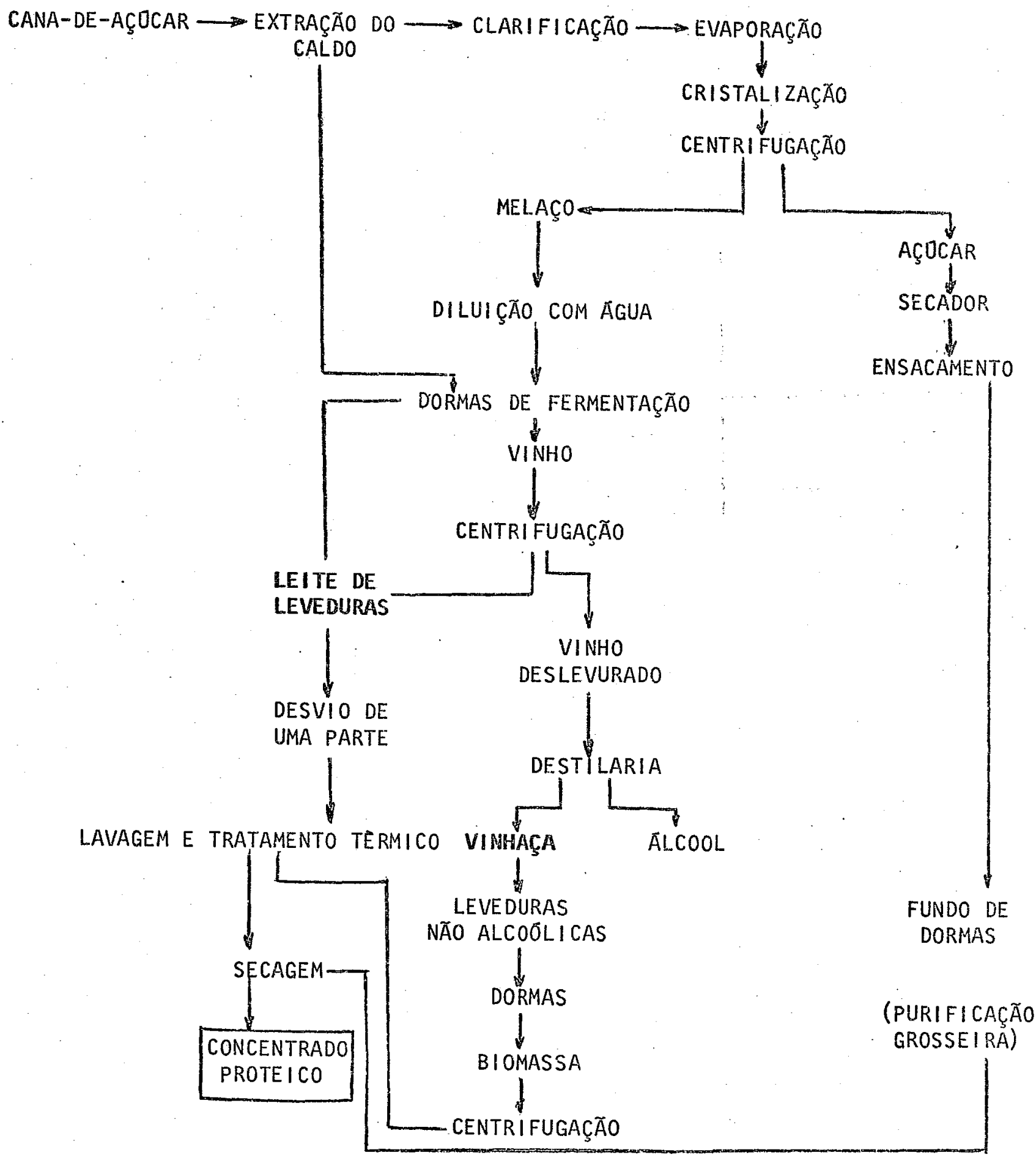

Figura 4 - Esquema da produção de ālcool e de levedura para obtenção de concentrado proteico.

FONTE : MACHADO, 1983 
Tabela 8 - Composição bromatológica de diferentes tipos de leveduras e do farelo de algodão (em 100\% da M.S.).

\begin{tabular}{|c|c|c|c|c|}
\hline \multirow{2}{*}{ DETERMINAÇ̃̃ES } & \multicolumn{4}{|c|}{ AMOSTRAS } \\
\hline & 1 & 2 & 3 & 4 \\
\hline & & & & \\
\hline - Matéria seca & 91,92 & 93,00 & 95,40 & 90,00 \\
\hline - Proteiria bruta $(N \times 6,25)$ & 30,98 & 48,30 & 57,40 & 31,00 \\
\hline - Extrato: etéreo & 1,50 & 1,61 & 3,56 & 1,28 \\
\hline - Fibra bruta & 0,94 & 3,00 & 0,10 & 25,00 \\
\hline- Cinza & 4,27 & 6,28 & 7,86 & 6,13 \\
\hline - Extrativo não nitrogenado & 62,31 & 40,81 & 30,72 & 36,59 \\
\hline - Energia bruta Mcal/kg & 4,37 & - & - & - \\
\hline
\end{tabular}

1. Levedura seca, utilizada no presente trabalho.

2. Levedura de cervejaria (NATIONAL RESEARCH COUNCIL, N.R.C., 1978).

3. Levedura cultivada em hidrocarbonetos (TEGBE \& ZIMMERMAN, 1977).

4. Farelo de algodão, utilizado no presente trabalho.

FONTE: MACHADO, 1983.

Jả há alguns anos, pesquisadores vem estudan do a composição química e a capacidade potencial de utilizą ção da levedura não somente obtida durante a produção de á1 cool, mas também na indústria de bebidas e indūstria química (JACQUOT, 1943).

ENSMINGER (1970) ressaltou não somente o ele vado teor proteico das leveduras como tambêm as classificou entre as melhores fontes proteicas de origem vegetal. 0 mes mo jā havia sido afirmado por JACQUOT (1943), que afirmou 
que a qualidade da proteína das leveduras se aproxima das de origem animal, atribuindo àquelas um valor biológico de $87 \%$.

o valor biológico da proteîna das leveduras foi comparado por Mc NAUGHT et a1ii (1954) ao dos protozoa rios e bactérias do rümem, em trabalhos com ratos. Os valo res encontrados foram 81,80 e 72 , respectivamente para as proteinas de bactêrias, protozoários e levedura. Os autores determinaram tambëm as digestibilidades verdadeiras, que fo ram de 74,91 e $84 \%$ na mesma ordem. Com base nesses resulta dos, os autores concluíram ser interessante para o hospede ro a conversão da proteína de levedura em proteína bacteria na ou de protozoários.

O efeito do uso de leveduras sobre a retenção de nitrogênio e digestibilidade de raçōes para gado de corte foi observado por Le GENDRE et alii (1957). Em testes de digestibilidade e balanço de nitrogênio com novilhos, a adição de levedura à forragem de baixa qualidade e forragem de alta qualidade reduziu a digestibilidade do extrato etéreo em cada ração sem afetar a digestibilidade dos outros nutrientes.

SOLIVA (1985) comparou o efeito da substitui ção do farelo de soja por levedura sobre a digestibilidade de rações para bezerros. As rações experimentais constituíam-se de 3 proporçôes de volumosos $(30,50$ e $70 \%)$ e 3 ní 
veis de substituiçāo de farelo por levedura $\left(0 \frac{\circ}{\circ}, 50^{\circ}\right.$ e $\left.100 \%\right)$. Para diferentes niveis de concentrado e de levedura nāo foram encontrados efeitos significativos entre os coeficientes de digestibilidade da M.S. (matêria seca), M.O. (matéria original), P.B. (proteína bruta), E.N.N. (extrativo nāo ni trogenado) e energia. Com o aumento do níve1 de concentrado houve redução significativa no coeficiente de digestibilida de da PB. Em função dos resultados a autora concluiu ser vi ável o uso da levedura em substituiçāo ao farelo de soja em concentrados, associada a três níveis de volumoso.

As pesquisas considerando o uso da levedura em rações para ruminantes têm entrado no campo tanto da pe cuâria de corte como na pecuâria de leite.

Utilizando rações isoproteicas e isocalóricas; REICHERT et alii (1984) substituiram o farelo de semente de algodão por levedura desidratada de cana-de-açücar na alimentação de vacas em lactação. Todas as vacas recebiam 0,33 $\mathrm{kg}$ de concentrado por litro de leite produzido e tinham acesso à pastagem seca de inverno. Os autores não observaram diferença estatística entre os tratamentos que continham $\underline{\text { a }}$ té $33 \%$ de levedura seca no concentrado.

MACHADO (1985), substituindo farelo de algo dão por levedura seca em até $37 \%$ da proteína da dieta, observou que as rações contendo levedura apresentaram: 1) maior eficiência digestiva; 2) menor recuperaçāo da produção de 
leite em relação à produção do período de depleçāo proteica; 3) maior produção de proteína do 1eite; 4) mesma atividade metabólica a nîvel de rúmem; 5) nenhum efeito adverso na composição do leite e nos parâmetros sanguíneos. Em função dos resultados o autor recomenda a utilização da levedura no arraçoamento de vacas em lactação, nos níveis daquele tra balho.

Em trabalho em que comparou a levedura seca com farelo de algodão, em dietas contendo como volumoso ba gaço de cana e palha de milho mais sabugo, PACOLA et alii (1985) não observaram diferença entre os ganhos de peso dos animais que receberam levedura e os ganhos dos animais que receberam farelo de algodão. 


\section{MATERIAIS E METODOS}

o trabalho foi realizado no município de Pre sidente Venceslau-SP, na Destilaria de Alcool Caiuä S/A, e teve a duração de 12̣2, dias entre junho e dezembro de 1985. A destilaria não dispunha ainda do equipamento para hidrổi se e o bagaço hidrolisado foi fornecido, periodicamente, pe la Destilaria Alcídia S/A, tendo sido armazenado na forma de silagem.

A levedura de sangria e o concentrado de vi nhaça foram adquiridos junto a duas destilarias da região, que já as produziam comercialmente. Foram analisadas e esto cadas sem problemas durante todo o experimento, devido ao baixo teor de umidade: 13,14\% para a levedura de sangria e $7,83 \%$ para o concentrado de vinhaça.

Convêm salientar que, de acordo com o fabri cante da vinhaça concentrada seca, ocorrem centrifugações sucessivas no processo de concentraçāo antes da secagem, o que é coerente com a análise bromatológica onde observaram-se teores de minerais bem inferiores $(7,42 \%$ da M.S.) àque les encontrados na literatura para a vinhaça apenas concen trada ( 18 a $22 \%$ da M.S.). Este fato reduz consideravelmente - risco de se trabalhar com excesso de minerais como o potássio. 


\subsection{Condições de Hidrólise do Bagaço}

Seguindo a metodologia utilizada por BURGI (1985), foram realizados värios tratamentos envolvendo diversas combinaçōes de tempo e pressão. De cada tratamento foram tomadas amostras para determinação da digestibilidade in vitro da M.S.. Com base nas anälises, estabeleceu-se a curva de operação do equipamento, que indicava uma pressão de $17 \mathrm{kgf} / \mathrm{cm}^{2}$ e o tempo de 5 minutos como a melhor condição de tratamento para o início da safra na Destilaria Alcídia S/A. O bagaço, assim obtido, foi utilizado para o experimen to.

o aparelho utilizado para o tratamento foi produzido pela CALDEMA - Calderaria e Máquinas Agrícolas, e consiste basicamente de uma câmara de pressão conforme ilus tra a Figura 5 . 


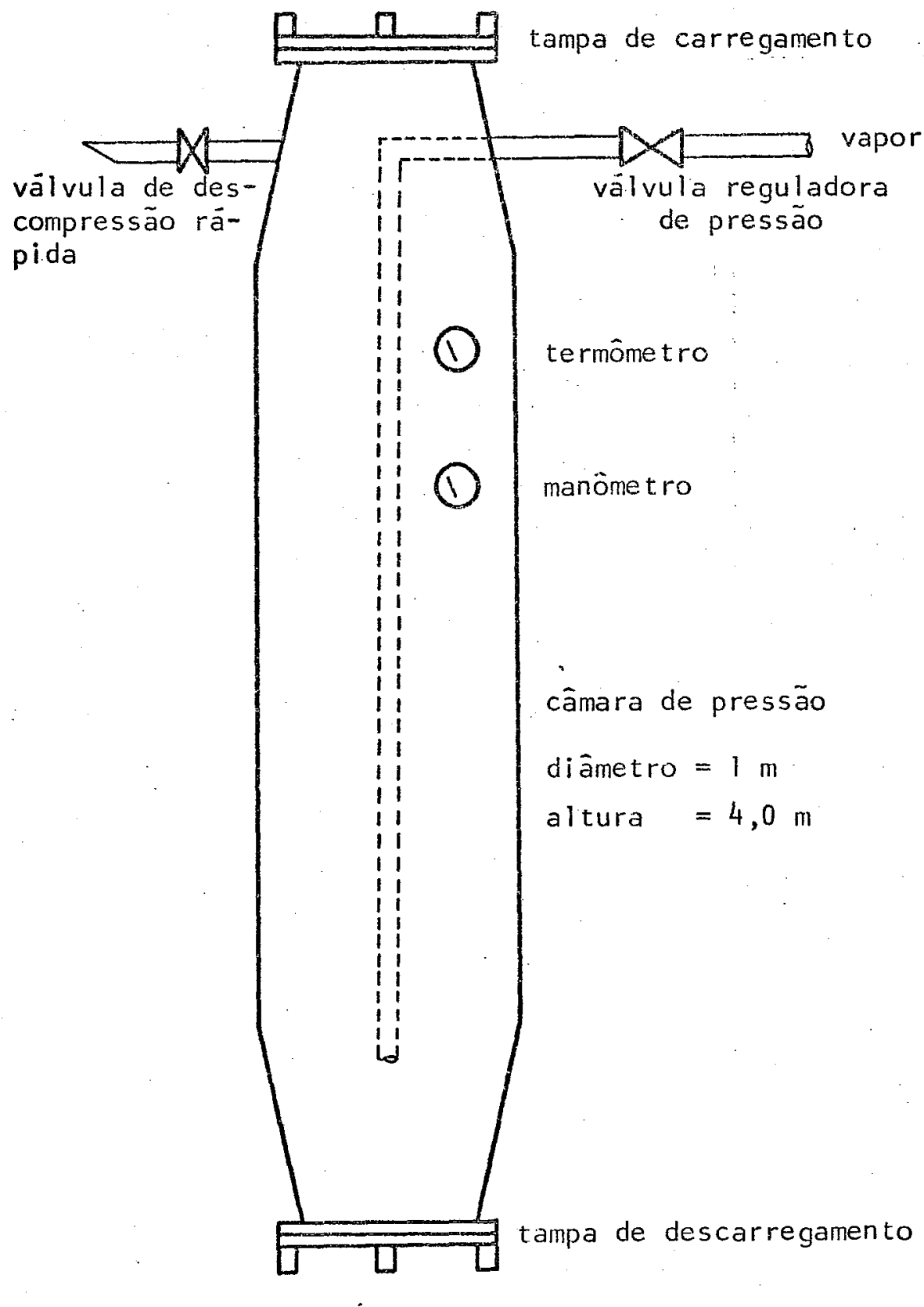

Figura 5 - Esquema do equipamento de auto-hidrôlise do bagaço de cana (Cap.: $400 \mathrm{~kg}$ bagaço/batelada).

FONTE: BURGI (1985) 


\subsection{Teste de ganho de Peso}

o presente trabalho teve como objetivo compa rar os efeitos do uso de duas diferentes fontes de proteina, produzidas a partir da fabricação de açücar e ālcöol, com uma fonte proteica tradicional, o farelo de algodão, quanto ao ganho de peso de bovinos confinados. Em todas as rações, o principal volumoso foi o bagaço de cana auto-hidroljsado (50\% da M.S.) BAH, e o volumoso suplementar à cana picada, completando $62,5 \%$ de volumoso na M.S. da raçäo completa.

Foram utilizados 36 novilhos de corte mestiços zebu europeu, com idade entre 18 e 30 meses e peso médio inicial de $316,5 \mathrm{~kg}$. Por ocasião da separação dos lotes e nício da adaptação, todos os animais foram vermifugados, va cinados contra febre aftosa, implantados com Ralgro, identi ficados com brincos plásticos e receberam vitamina ADE. Fo ram utilizados 3 piquetes de piso de terra com $300 \mathrm{~m}^{2}$ cada e uma área por animal de $20 \mathrm{~m}^{2} /$ cabeça. Durante a adaptação havia $15^{`}$ animais por piquete, sendo 3 de reserva em cada tra tamento, nāo utilizados no experimento. A base dos cochos, do lado interno, foi feita uma faixa cascalhada de $2 \mathrm{~m}$ para evitar o acúmulo de lama. Com o mesmo objetivo, absorção da umidade das fezes, urina e chuvas eventuais, foi colocado sobre o piso dos piquetes uma camada de bagaço in natura, o qual, atê o final do confinamento, junto com o.esterco, for- 
mou um composto orgânico utilizado como fertilizante. Semanalmente, era realizado rodízio dos animais pelos piquetes, de modo que todos os tratamentos permaneceram o mesmo nümero de dias em cada piquete, passando por todos.

0 período de adaptação teve a duração de 10 dias. Durante esse período os animais receberam rações com menores proporções de BAH e maiores percentuais de cana pí cada. As proporções de BAH e uréia foram aumentadas gradati vamente ate 0 início do período experimental propriamente dito.

0 período experimental teve início em $04 / 07 /$ 85. Nesse dia os novilhos foram pesados e separados de acor do com o peso inicial em 3 lotes de 12 animais, e os tratamentos sorteados aos lotes. O período experimental esten deu-se até $24 / 10 / 85$, com a duração de 112 dias.

Os tratamentos utilizados foram:

T.1 - Ração com farelo de algodão - ração completa com 50\% de BAH (17/5) na M.S., $12,7 \%$ de farelo de algodão, $17,8 \%$ de milho grão e $12,5 \%$ de cana integral picada.

T.2 - Ração com levedura de sangria - ração completa com $50 \%$ de BAH $(17 / 5)$ na M.S., $12,7 \%$ de levedura de sangria (seca) $, 17,8 \%$ de milho grão e $12,5 \%$ de cana integral picalda. 
T.3 - Raçäo com concentrado de vinhaça - ração completa com $50 \%$ de BAH (17/5) na M.S., 12,7\% de concentrado de $v \underline{i}$ nhaça, $17,8 \%$ de milho grāo e $12,5 \%$ de cana integral picada.

As raçöes completas eram fornecidas pela ma nhã, e as sobras pesadas no dia seguinte antes do novo for necimento. O fornecimento era mantido em níveis capazes de proporcionar sobras da ordem de $10 \%$. As medidas de fornecimento e sobras e, consequentemente, de consumo, eram toma das em relação ao lote, uma vez que os piquetes eram coletį vos.

Parte do sal comum, sal mineral e uréia foram misturados à ração completa, sendo que a uréia era prế viamente diluída no caldo de cana com $12^{\circ}$ Brix. Em todos os piquetes havia cochos de sal comum à disposição dos noví 1hos.

Os alimentos concentrados utilizados foram ad quiridos de uma só vez e amostrados no início dos trabalhos para a formulação das raçōes. A cada 15 dias eram colhidas amostras dos alimentos volumosos e das raçōes completas para compor uma amostra média, analisadas posteriormente se gundo a "ASSOCIATION OF OFFICIAL AGRICULTURAL CHEMISTS" (A. O.A.C., 1970) e Van SOEST (1963).

Todos os animais foram pesados individualmen 
te no início do experimento, no início do período de comparação e sucessivamente a cada 14 dias ate o final do experi mento, sempre com jejum prêvio de 14 horas.

Tabela 9 - Composição das rações e consumo estimado em kg de matēria original (M.0.) por cabeça por dia.

\begin{tabular}{|c|c|c|c|c|c|c|}
\hline \multirow{2}{*}{ ALIMENTOS } & \multicolumn{2}{|c|}{ TRATAMENTO 1} & \multicolumn{2}{|c|}{ TRATAMENTO 2} & \multicolumn{2}{|c|}{ TRATAMENTO 3} \\
\hline & $\begin{array}{c}\mathrm{kg} \\
\text { MO/CAB.D }\end{array}$ & A \%MS & $\begin{array}{c}\mathrm{kg} \\
\mathrm{MO} / \mathrm{CAB} . \mathrm{DIA}\end{array}$ & \%MS & $\begin{array}{c}\mathrm{kg} \\
\mathrm{MO} / \mathrm{CAB} . \mathrm{DIA}\end{array}$ & $\%$ MS \\
\hline Bagaço hidrolisado & 9,70 & 50,1 & 9,70 & 49,9 & 9,70 & 49,8 \\
\hline Cana picada & 3,80 & 12,5 & 3,80 & 12,5 & 3,80 & 12,5 \\
\hline Fare lo de algodão & 1,31 & 12,7 & - & - & - & - \\
\hline Levedura de sangria & - & 一 & 1,33 & 12,7 & - & - \\
\hline Levedura de vinhaça & - & - & - & - & 1,26 & 12,7 \\
\hline Milho grão & 1,80 & 17,8 & 1,80 & 17,7 & 1,80 & 17,7 \\
\hline Caldo $12^{\circ}$ Brix & 3,58 & 4,7 & 3,58 & 4,7 & 3,58 & 4,7 \\
\hline Urēia + sulfato amônia & 0,10 & 1,1 & 0,13 & 1,4 & 0,14 & 1,5 \\
\hline Mistura mineral & 0,10 & 1,1 & 0,10 & 1,1 & 0,10 & 1,1 \\
\hline TOTAL & $* 20,39$ & 100,0 & * 20,44 & 100 & $* 20,38$ & 100 \\
\hline
\end{tabular}

\begin{tabular}{llllllllll}
\hline COMPOSIÇÃO DA RAÇÃOO & MS & PB & NDT & MS & PB & NDT & MS & PB & NDT \\
\hline $\begin{array}{l}\text { PRINCTPIOS } \\
\text { NUTRITIVOS }\end{array}$ & 44,7 & 10,8 & 57,9 & 44,7 & 10,7 & 57,8 & 44,9 & 10,8 & 57,7
\end{tabular}

* As quantidades em $\mathrm{kg}$ de matëria original (MO) por cabeça/dia referem-se ao início do experimento, posteriormente, em função do consumo as quantidades fornecidas foram aumentadas, mantendo-se a proporção en tre os alimentos.

M.S. = Matéria Seca

NDT = Nutrientes Digestíveis Totais

$P B=$ Proteína Bruta 


\subsection{Procedimento Estatístico}

o delineamento estatístico foi casualizado com 3 tratamentos e 12 repetições. Os dados de peso vivo inicial (P.V.I.), peso vivo final (P.V.F.) e ganho de peso diärio (G.P.D.) foram submetidos a anälise de variância, e as mëdias de G.P.D. foram comparadas pelo teste de Tukey. 


\section{RESULTABOS E DISCUSSÃO}

Todos os animais tiveram comportamento normal durante o experimento, não se observando qualquer pro blema clînico e nenhuma alteração na consistência das fezes. Com relação ao preparo das raçōes completas, observou-se que o concentrado de vinhaça era mais higroscó pico do que a levedura seca e o farelo de algodão. Esse fato é coerente com os dados de PUPO (1981), que atribuiu ao concentrado de vinhaça um efeito aglutinador de partículas de ração, em função da absorção de umidade dos outros alimentos.

\subsection{Consumo e Conversão Alimentar}

o resultado das análises bromatológicas dos alimentos empregados na composição das rações completas encontra-se no apêndice. Todo o bagaço auto-hidrolisado utili zado foi previamente ensilado em superfície, uma vez que era produzido na Destilaria Alcídia e depois transportado pa ra o local do experimento. Foram tambêm realizadas análises 
de minerais da levedura e do concentrado de vinhaça (Tabela 3 do apêndice).

As rações foram formuladas realizando-se os ajustes de proteína às custas de alteraçōes nos teores de $\underline{u}$ réia dos tratamentos 2 e 3 (levedura e vinhaça) em relação à 1 (algodão).

As análises bromatológicas das rações comple tas confirmaram que as formulações foram adequadas, uma vez que praticamente não diferiram com relação aos princípios nutritiyos estimados (Tabela 10).

Observa-se também que a digestibilidade das 3 rações não diferiu, fato este que indica as boas condições de tratamento e armazenamento do bagaço auto-hidrolisado em pregado.

Os consumos mëdios apresentados em todo o pe ríodo experimental foram de 21,$9 ; 22,5$ e $19,5 \mathrm{~kg}$ de Matëria Original (M.0.) por cabeça por dia e de 9,85; 10,21 e 8,66 $\mathrm{kg}$ de MS/cabeça por dia, respectivamente para os tratamentos 1 (a.1godão), 2 (1evedura) e 3 (vinhaça). Esses resultados são semelhantes aos obtidos por BURGI (1985), que também tra ba1hando com rações completas, contendo 40,50 e $60 \%$ de BAH na Matéria Seca e 60\% de bagaço in natura na Matéria Seca e farelo de algodão como fonte de proteína, observou consumos de 9,$92 ; 10,00 ; 10,13$ e $6,71 \mathrm{~kg}$ de MS/cab.dia, respectivamente para as 4 rações utilizadas nos tratamentos. A evolu 
Tabela 10 - Composição das rações completas em princípios nutritivos.

\begin{tabular}{lrrr}
\hline DISCRIMINAÇÃO & $\begin{array}{c}\text { TRAT. } 1 \\
\text { ALGODÄO }\end{array}$ & $\begin{array}{l}\text { TRAT. } 2 \\
\text { LEVEDURA }\end{array}$ & $\begin{array}{c}\text { TRAT. } 3 \\
\text { VINHAÇA }\end{array}$ \\
\hline em \% da MO & & & \\
MS & 44,98 & 45,38 & 44,40 \\
em \% da MS & & & \\
PB & 11,37 & 10,42 & 11,17 \\
FB & 29,37 & 27,40 & 23,89 \\
EE & 1,22 & 1,22 & 0,80 \\
MM & 4,33 & 5,29 & 4,62 \\
ENN & 53,71 & 56,67 & 59,62 \\
ADF & 42,16 & 38,64 & 38,31 \\
NDF & 50,51 & 46,38 & 47,13 \\
Cin NDF & 1,71 & 2,30 & 2,25 \\
ADL & 10,68 & 8,84 & 8,75 \\
DiVIV(MS) & 67,97 & 70,01 & 69,96 \\
\hline
\end{tabular}

$\mathrm{PB}=$ proteína bruta; $\mathrm{FB}=$ fibra bruta; $\mathrm{EE}=$ extrato etēreo; $M M=$ mate ria mineral; $E N N=$ extrativo não nitrogenado; $A D F=$ fibra em detergente ácido; $N D F=$ fibra em detergente neutro; $\operatorname{Cin} N D F=$ cinza da parede celu lar; $A D L=$ lignina em detergente ácido; $\operatorname{DiVIV}(M S)=$ digestibilidade in vétro da matéria seca; M.S. = matéria seca. 
ção dos consumos durante o período experimental pode ser ob servada na Tabela 11 e Figura 6 .

Tabela 11 - Consumo das rações completas, médias semanais por tratamen to.

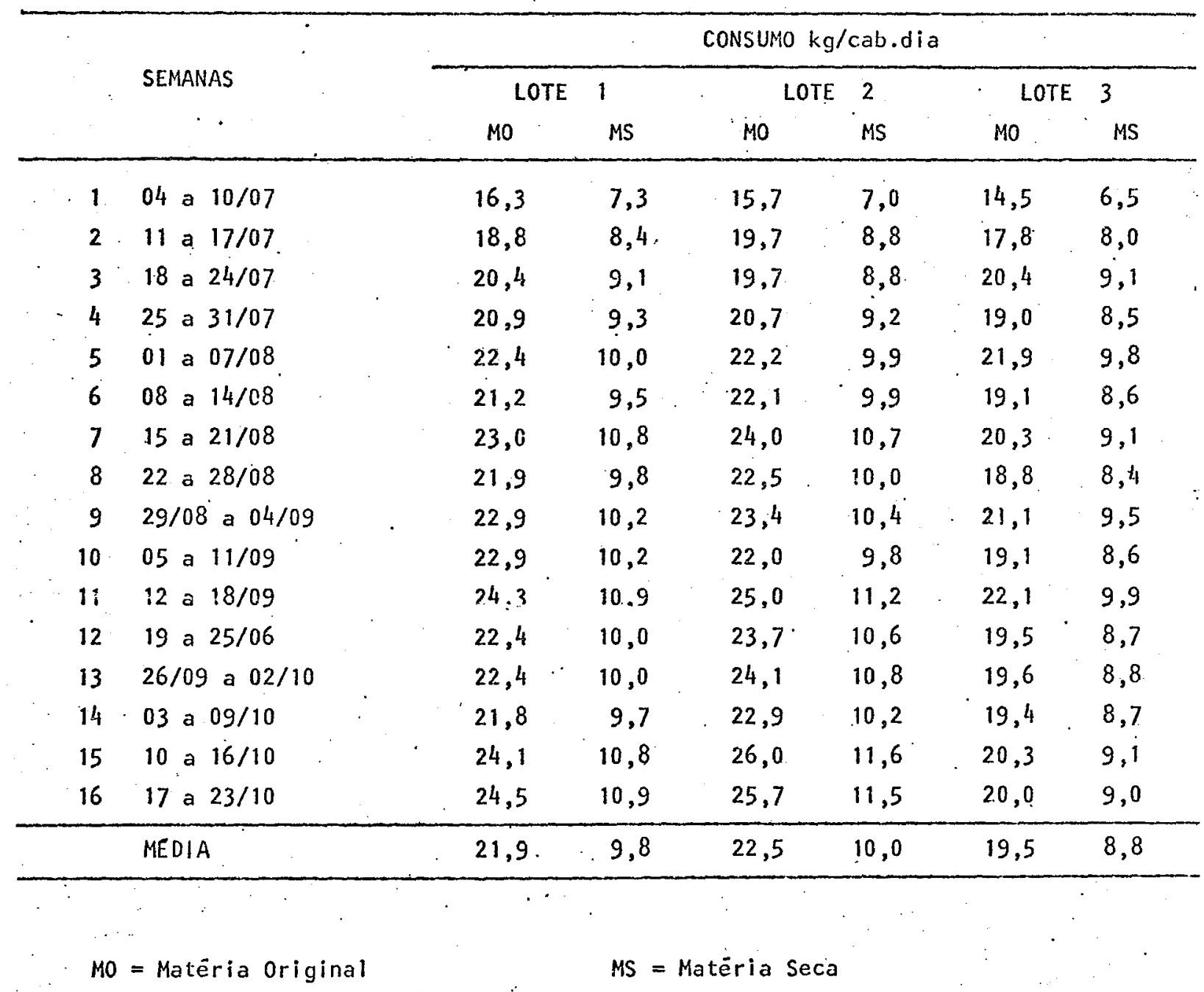




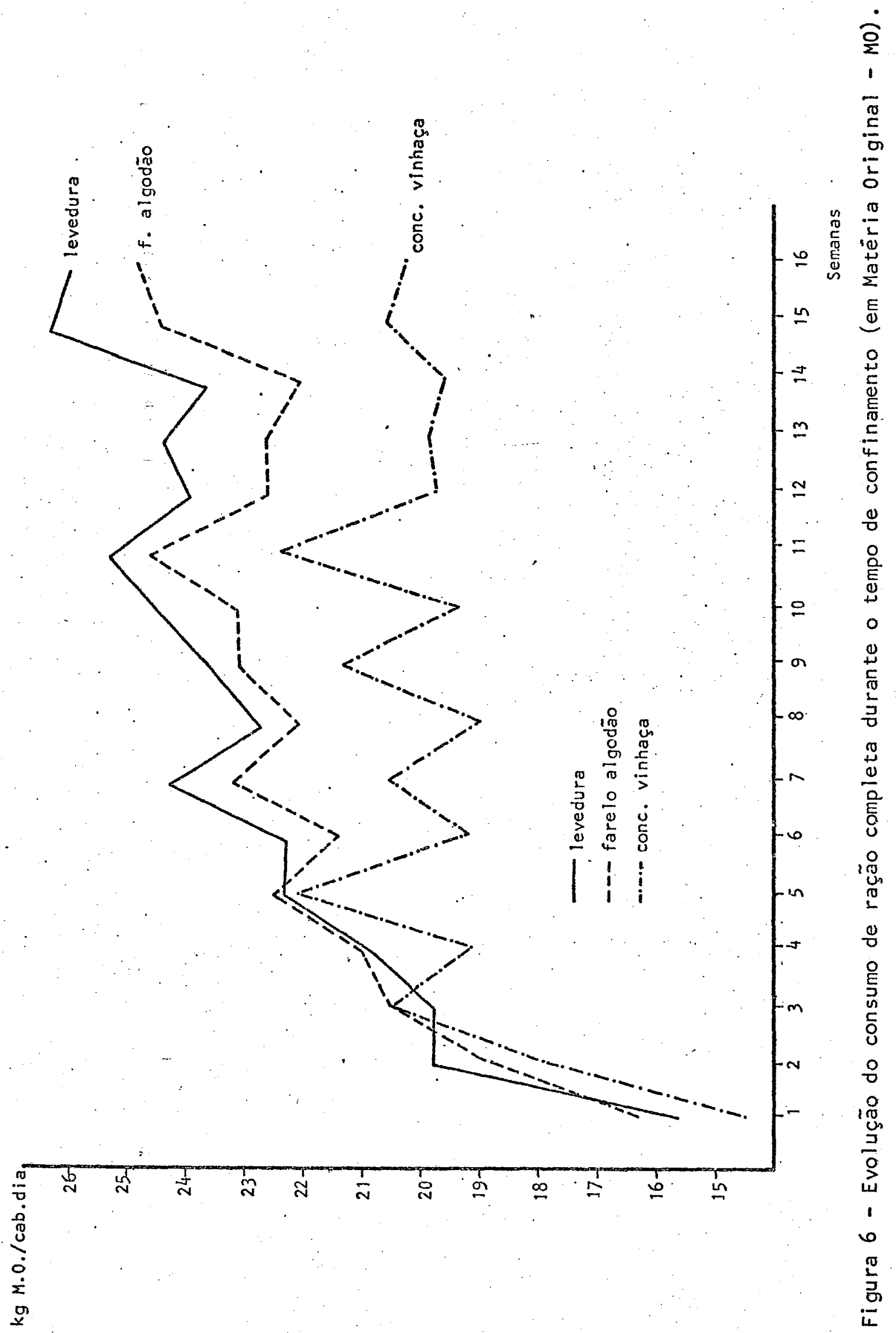


Como se observa pela Figura 6 e Tabela 11 o consumo da ração no 3 (vinhaça) foi muito irregular, o que acarretou resultados inferiores em ganho de peso. Os consumos das rações n̊ 1 e 2 mantiveram-se por sua vez muito prô ximos, o que também refletiu sobre os ganhos de peso obser vados.

o baixo consumo obtido com a ração contendo concentrado seco de vinhaça está de acordo com os resultados obtidos por PIEKARSKI (1983), o qual, trabalhando com vinhaça concentrada em substituição ao melaço, em rações con tendo milho desintegrado com palha e sabugo 65\% da (MS) notou redução de consumo das rações contendo vinhaça. Conside rou possível a substituição apenas parcial do melaço pela vinhaça em niveis de 33 a $66 \%$, que correspondiam, respecti vamente, a 10,99 e $21,97 \%$ de vinhaça na M.S. das rações com pletas. PUpo (1981) também observou redução no consumo de M.S. em rações contendo vinhaça concentrada substituindo me 1aço. Este fato foi atribuído à baixa palatabilidade da vinhaça sem, entretanto, ocorrerem efeitos tóxicos.

Essa redução na palatabilidade das rações contendo vinhaça concentrada poderia ser atribuída às fontes e proporções de potâssio nela existente, o que estaria de acordo com os trabalhos de NEATHERY et alii (1980), que observaram redução na palatabilidade de raçōes ao utilizarem determinadas fontes de potássio em quantidades que prọ 
porcionaram mais que $2:$ do elemento na dieta. Entretanto, os baixos teores de matéria mineral total encontrados na vinha ça seca concentrada e principalmente o baixo teor de potäs sio $\left(1,1 \%\right.$ de $K_{2} O$ total) não justificam a redução do consumo com base nesse fato, pois nos trabalhos de NEATHERY et alii (1980) não ocorreram alteraçōes de consumo para nenhuma fon te de K utilizada até o nível de $2 \%$ da dieta. Outro resulta do que conduz à idéia de não ser o potâssio responsāvel pe1a redução de consumo, é o fato da ração com levedura ter sido a mais consumida, e nela o teor de $\mathrm{K}_{2} \mathrm{O}$ total foi de $3,0 \%$ praticamente o dobro do encontrado na ração contendo vinhaça.

0 consumo de Matéria Seca proporcional ao pe so vivo foi de $2,68,2,74$ e $2,48 \%$, respectivamente para as rações 1,2 e 3 , e a conversão alimentar foi de $11,7,10,3$ e $14,9 \mathrm{~kg}$ de $\mathrm{MS} / \mathrm{kg}$ de GPD. Esses resultados demonstram a in ferioridade do tratamento 3 em relação ao 2 e ao 1 . Esses dois ültimos, por sua vez, são compativeis com os resultados obtidos por BURGI (1985) que, trabalhando também com ra ções completas contendo atê $60 \%$ de bagaço auto-hidrolisado na M.S., obteve conversões alimentares de 10,$33 ; 12,25$ e $11,25 \mathrm{~kg}$ de $\mathrm{MS} / \mathrm{kg}$ de ganho de peso em bovinos alimentados com rações contendo, respectivamente, 40,50 e $60 \%$ de BAH $(17 / 5)$ na MS.

A baixa conversão alimentar da ração 3 (vi- 
nhaça) não $\vec{e}$ coerente com os resultados obtidos por pUPo (1981), que nāo encontrou diferenças de conversão alimentar em rações contendo vinhaça concentrada em substituição ao melaço, embora tenha ocorrido redução do consumo da ração com vinhaça.

\subsection{GANHO DE PESO}

os valores das pesagens realizadas no inicio e no final do experimento e a cada 14 dias encontram-se na Tabela 12 e na Tabela 4 do apêndice.

Tabela 12 - Ganho de peso diärio (G.P.D.) mëdio - 112 dias.

\begin{tabular}{|c|c|c|c|}
\hline \multirow{2}{*}{ TRATAMENTO } & \multicolumn{2}{|c|}{ PESO VIVO $(\mathrm{kg})$} & GPD $(\mathrm{kg})$ \\
\hline & INICIAL & FINAL & MEDIA 112 DIAS \\
\hline 1- ALGODÃO & $318,75 \pm 8,26$ & $413,17 \pm 9,79$ & $0,843 \pm 0,047 a$ \\
\hline 2- LEVEDURA & $316,25 \pm 7,33$ & $427,08 \pm 8,69$ & $0,989 \pm 0,040 a$ \\
\hline 3- VINHAÇA & $314,50 \pm 12,00$ & $379,50 \pm 16,61$ & $0,580 \pm 0,051 b$ \\
\hline
\end{tabular}


Como se observa, foram encontradas diferenças significativas a favor das raçōes 1 e 2 quando compara das com a 3 , não ocorrendo diferenças significativas entre as duas primeiras nem mesmo ao nivel de $5^{\circ}$ pelo teste de Tu key.

Esses resultados indicam ser possíve1 a sub $\underline{s}$ tituição do farelo de algodão por levedura de sangria, em rações completas para confinamento, utilizando bagaço hidro lisado, conferindo assim maior autonomia às usinas e destilarias e são compatíveis com os obtidos por PACOLA et alii (1985), que não encontraram diferença entre o ganho de peso de bovinos alimentados com concentrados contendo levedura em substituição ao farelo de algodão, e aos obtidos por MACHADO (1983), que trabalhando com vacas em lactação, não ob servou efeitos sobre a produção e composição do leite no período de comparação ao substituir o farelo de algodão por levedura em concentrados componentes de rações completas à base de silagem de milho. O autor atribui ainda, a um me1hor balanceamento de aminoäcidos na levedura a elevação da produção de leite para esse tratamento em relação ao período de depleção.

O resultado inferior de Ganho de Peso Diário (G.P.D.) dos animais do tratamento 3 (concentrado de vinha ça) era esperado devido a irregularidade do consumo durante o período experimental. Este fato pode ser atribuído à bai- 


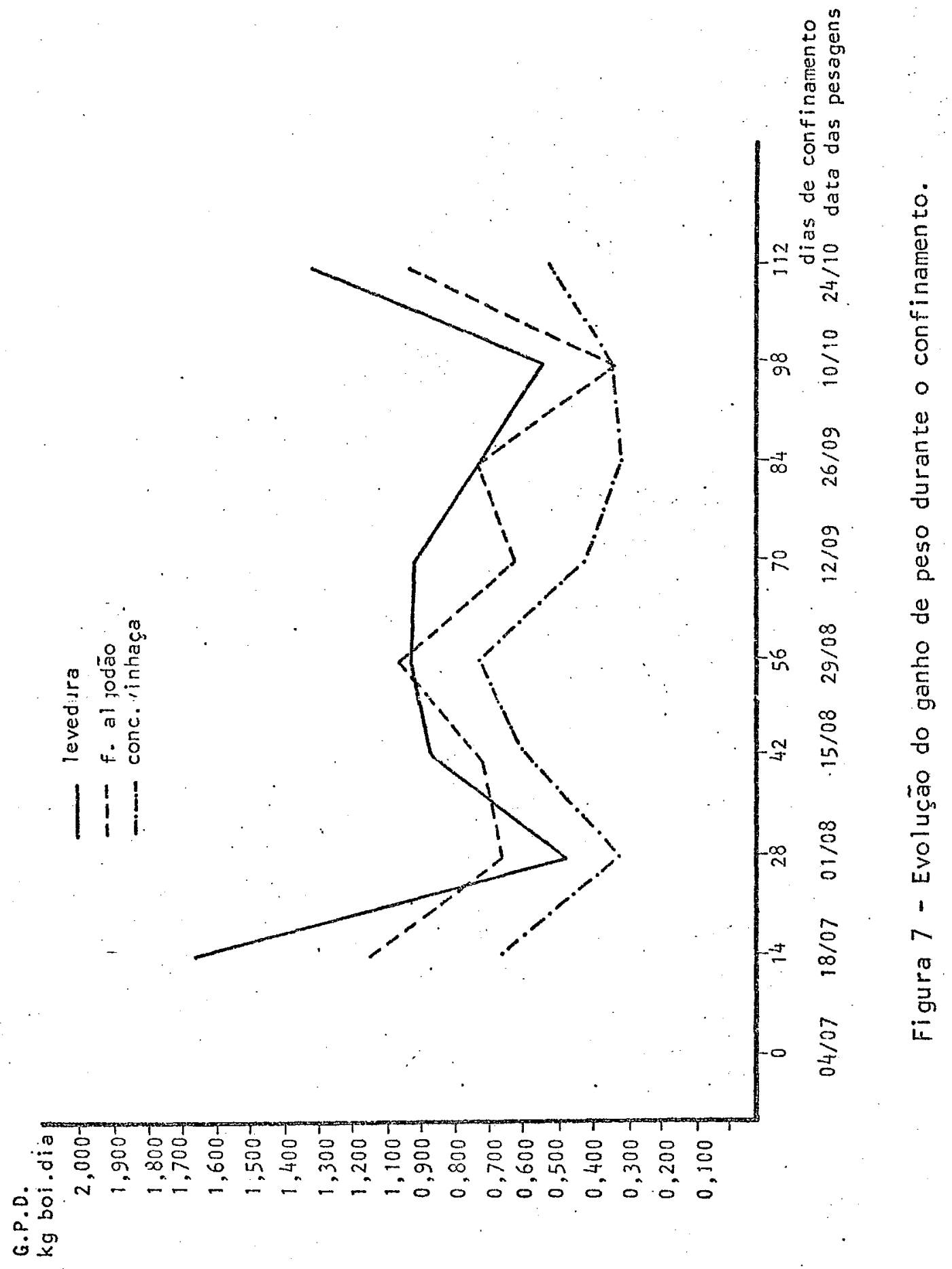


xa palatabilidade do concentrado de vinhaça, estando de acordo com os resultados obtidos por PUPO (1981), que também observou reduções no consumo de M.S. e G.P.D. de bovinos alimentados com vinlaça concentrada em substituição ao mela ço, limitando o uso da vinhaça concentrada em até $7 \%$ da MS, em função de sua baixa palatabilidade.

Alêm da baixa palatabilidade, pode-se asso ciar os baixos niveis de consumo, no tratamento com con centrado de vinhaça, à maior higroscopicidade desse alimento, o que provocava a formação de grumos na ração completa. Pode-se acrescentar ainda que, embora possível do ponto de vista nutricional substituir o farelo de al godão pela levedura de sangria, devem ser considerados os aspectos econômicos dessa substituição ano a ano, uma vez que a levedura de sangria seca tem bom valor de mercado e jâ vem sendo utilizada na fabricação de concentrados, principalmente para monogástricos, o que é coerente com os re sultados obtidos por MIYADA (1978), que trabalhando com 36 marrãs das raças Large White $x$ Landrace e Wessex, não notou influência no ganho de peso diário dos suinos alimentados com rações contendo até $21^{\circ}$ de levedura seca na MS durante as fases de crescimento, acabamento e crescimento- acabamen to. Notou, ainda, que com o aumento do nível de levedura se ca na dieta, houve uma tendência em aumentar o consumo diärio de ração durante a fase de crescimento e aumento linear 
de consumo e/ou con o aumento dos níveis de levedura nas fases de acabamento e crescimento-acabamento. A qualidade de carcaça foi melhorada com a elevação dos niveis de levedura seca, pois, alêm de uma tendência em diminuir a espessura do toi cinho, houve uma redução linear da relaçāo gordura-carne, e um aumento linear da porcentagem de pernil. A melhor qualidade das carcaças dos suinos alimentados com raçöes contendo niveis mais elevados de levedura seca foi atribuída ao aumento do consumo diärio de proteína e lisina.

No ano de 1985 , em que se realizou o experimento, ficou clara a superioridade do farelo de algodão em relação à levedura em termos de resultados econômicos, pois o mesmo foi adquirido a $\operatorname{Cr} \$ 350,00 / \mathrm{kg}(0,0075$ oTN $/ \mathrm{kg})$ contra Cr\$ $800,00 / \mathrm{kg}(0,0190$ OTN $/ \mathrm{kg})$ da levedura. O lote alimentado com farelo de algodão proporcionou um lucro líquido de 362 OTNs (Cr\$22.981.000 nov./85) e una rentabilidade de $23 \%$ ao mês contra um Iucro líquido de 338 OTNs (Cr $\$ \ldots \ldots$ 21.482 .239 nov./85) e rentabilidade de $21,5^{\circ}$ ao mês na operação do confinamento do lote de levedura. 


\section{CONCLUSÕES}

1.) No nível testado $(12,7 \%$ da M.S. $)$, a leve dura de sangria pode substituir o farelo de algodão em rações completas para confinamento contendo $50 \%$ de bagaço au to-hidrolisado, sem prejuízo do consumo, ganho de peso e conversão alimentar dos bovinos.

2a) Os resultados de consumo e conversão ali mentar também foram superiores para a ração com levedura de sangria quando comparados aos outros tratamentos, o que jus tifica sua utilização em rações de confinamento como fonte de proteina.

3.) Deve-se considerar a cada ano os aspectos econômicos da substituição do farelo de algodão por le vedura, pois em função dos preços desses alimentos, o resul tado econômico pode ser negativo como ocorreu no experimento.

4.) Os resultados obtidos com as rações 1 e 2 confirmam ser possível o uso de bagaço de cana auto-hidro 1isado em rações completas para confinamento na proporção de 50 a $60 \%$ da M.S.. 


\section{BIBLIOGRAFIA CITADA}

ANGELIS, D.F.; KIYAN, C.; CORSO, C.R. e TAUK, S.M. Emprego de leveduras em culturas puras e mistas objetivando o aproveitamento de vinhaça. Brasil Açucareiro, n: 6, 17 22,1979 .

ARAUJO, N. de Q.; VISCONTI, A.S.; CASTRO, H.F. de; SILVA,H. G.B. da; FERRAZ; M.H.A.; SALLES FILHO, H. Produção de biomassa füngica de vinhoto. Rio de Janeiro. Seminärio Internacional Sobre Tratamento de Vinhoto. INT. (4) 1-12, 1976 .

ASSOCIATION ON OFFICIAL AGRICULTURAL CHEMISTS. Official Methods of Analysis. AOAC, Washington, DC, 1970.

BURGI, R. Produção do Bagaço de Cana-de-Açúcar Auto-Hidro lisado e Avaliação do seu Valor Nutritivo para Ruminantes. Piracicaba, SP. ESALQ-USP, 61p. (Tese de Mestrado) :

CAMHI, J.D. Tratamento do vinhoto subproduto da destilação de â1cool. Brasil Açucareiro, $\mathrm{n} \odot 1: 18-23,1979$. 
CAMPBELL, C.M.; WAYMAN, O.; STANLEY, R.W.; KAMSTRA, L.S.;OL BRICH, S.E.; HO-A, E.B. e NAKAYAMA, T. Effects of pressure treatment of sugar cane bagasse upon nutrient utili zation. Proc. Wistern. Sec. ASAS, E.U.A., 24:178-184, 1973.

CAMPOS, O.F.; SILVA, J.F.C. da; VILELA, H. e SOUZA, A.A.de. Valor nutritivo da raspa de mandioca e do bagaço de cana para ruminantes. Revista Ceres, 24(135): 521-529, 1977.

CARNEIRO, W. Economicidade da industria de leveduras. Brasi1 Açucareiro, $\mathrm{n} \% 1,16-23,1967$.

CROCHET, S.L. Blackstrap molasses, 1967. Major economic factor in catle operation at U.S. Sugar Corp. The Sugar Journa1, January, 1967.

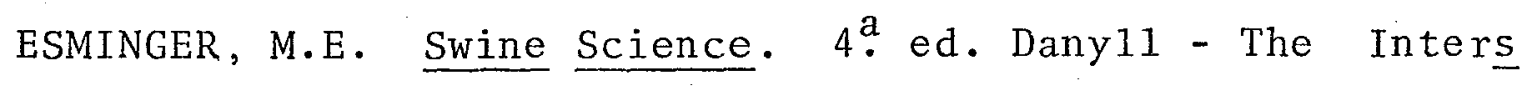
tate Printers e Publisher, Inc., 1970.

GLORIA, N.A.; SANTA ANA, A.g. e MONTEIRO, H. Composição dos resíduos de usina de açúcar e destilaria durante a safra canavieira. Brasil Açucareiro, 80 (5): 542-548, 1972. 
GLORIA, N.A.; SANTA ANA, A.G.; BIAGI, E. Composiçāo dos re síduos de usinas de açücar e destilarias. Brasil Açuca$\underline{\text { reiro, }} 81(6), 1973$.

GLÓRIA, N.A. Utilização agrícola da vinhaça. Brasil Açucareiro, $86(5): 11-17,1975$.

HART, M.R.; WALKER Jr., H.G.; GRAHAM, R.P.; GRAHAM, P.J.; HANNI, P.J.; BROWN, A.H. e KOHLER, G.O. Steam treatment of crop residues for increased ruminant digestibility.I.

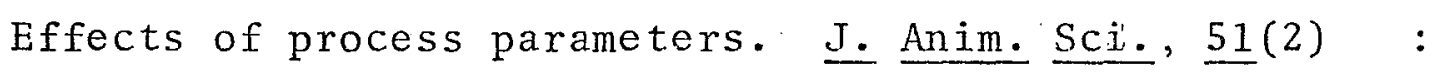
$402-408,1981$.

JACKSON, M.G. Treating straw for animal feeding. Anim. Prod. and Health Paper 10. Roma, Itâlia, FAO, 81p., 1978.

JACQUOT, R. Valor nutritivo das leveduras. Sua utilização prática para a alimentação humana. In: PAIVA, B.C., ed. 1966. Boletim Informativo da A.P.M.

JOSHI, A.L. e RANGNEKAR, D.V. Sugarcane bagasse based feed for growing cross-bred catle. Indian Vet. J., 56: 53-57, 1979 . 
LE GENDRE, G.R.; TOTUSEK, R. e GALLUP, W.D. Effect of live cel1 yeast on nitrogen retention and digestibility of ra tions by beef catle. J. Anim. Sci., 16: 671-674, 1957.

LEME, P.R.; YOSHINO, J.J. E NARDON, R.F. Torta de filtro, bagaço de cana e vinhaça na alimentação de bovinos em confinamento. Zootecnia, Nova Odessa, SP, 20 (4):205-21.7, 1982 .

LENNART, H. Methane production from Cassava Destillery Stillage with the Sorigona WWTS. Rio de Janeiro. Semina rio Internacional sobre Tratamento do Vinhoto I.N.T. (4) $39-44,1976$.

MACHADO, O.L.T. Descompressão rápida como pré-tratamento de madeira para a hidrólise enzimática. Rio de Janeiro, UFRJ/Inst. de Química, 1982. 80p. (Tese de Mestrado).

MACHADO, P.F. Valor nutritivo de levedura, resíduo da produção do á1cool, para vacas em lactação. São Paulo, SP, Fac. Ciênc. Farm.-USP, 1983. 110p. (Tese de Doutorado).

MARCOS, A.C.M.; LEME, P.R. e BOIN, C. Efeito do tempo de tratamento à pressão de vapor na composição química e na digestibilidade in vîtro da matéria seca do bagaço de cana-de-açúcar. Zootecnia, Nova Odessa, SP, 22 2 (4): 383-395, 1983. 
MC NAUGHT, M.L.; OWEN, E.C.; HENRY, K.M. e KKON, S. The utilization of non-protein nitrogen in the bovine rumen. Bio chem-Jo., 56: 151-156, 1954.

MIYADA, V.S. Uso de levedura seca de destilarias de älcool de cana-de-açücar na alimentação de suinos em crescimento e acabamento. Piracicaba, SP. ESALQ-USP. 106p. (Te se de Mestrado).

NEATHERY, M.W.; PUGH, D.G.; MILLER, W.J.; GENTRY, R.P. e WHITLOCK, R.H. Effects of sources and amounts of potassium on feed palatability and on potassium toxity in Dai ry Calves. J. Dairy Sci., 63: 82-85, 1980.

PACOLA, L.J.; RAZOOK, A.G. e LIMA, F.P. Aproveitamento do bagaço de cana-de-açúcar na engorda de bovinos confinados. Boletim da Indústria Animal, Nova Odessa, SP, 34(1) $25-28,1977$.

PACOLA, L.J.; CAIELLI, E.L.; MATTOS, J.C.A.; BOIN, C. e CAM POS, B.E.S. de. Levedura desidratada, bagaço de cana-de -açúcar e palha mais sabugo de milho na engorda de boví nos. Boletim da Indústria Anima1, Nova Odessa, SP, $\underline{42}(2)$ $149-153,1985$. 
PATE, F.M. Value of treating bagasse with steam under pres sure for catle feed. 'Trop. Agric., Trinidad, 59(14): $293-297,1982$.

PFEFFER, J.T. Methane fermentation of stillage. Rio de Ja neiro. Seminário Internacional sobre Tratamento do Vinhoto INT (4) : 13-38, 1976 .

PIEKARSKI, P.R.B. Valor nutritivo da vinhaça concentrada e do melaço na alimentação de bovinos em confinamento. Ví çosa, MG. U.F.V., 1983. 49p. (Tese de Mestrado).

PLANO CONSULTORIA AGROPECUÂRIA. Relatórios Técnicos finais de Confinamentos Comerciais, 1986.

PUPO, N.I.H. Substituição do melaço pela vinhaça concentra da na alimentação de novilhos de corte em regime de confinamento. Viçosa, MG. U.F.U., 1981. 49p. (Tese de Mestrado).

RANDEL, P.F. Ad libitum feeding of either a complete ration based on sugarcane bagasse or a conventional concentrates mixture to dairy cows. Journal of agriculture of university of Puerto Rico, 43(3): 429-443, 1970-a. 
RANDEL, P.F. Dairy beef production from mixtures of sugarcane bagasse and concentrates. Journal Agric. Univ. Puerto Rico, 54(2): 237-246, 1970-b.

RANDEL, P.F. Feeding lactanting dairy cows concentrates and sugarcane bagasse as compared with a conventional ration. J. Agric. Univ. Puerto Rico, 50(4): 255-269, 1966.

REICHERT, R.H.; VELLOSO, L.; PACOLA, L.J.; PINOTTI, R. e PROCKNOR, M. Utilização da levedura desidratada de cana -de-açúcar na alimentação de vacas leiteiras. Boletim Industr. Anim., Nova Odessa, SP, 1984.

ROMAN-PONCE, H.; VAN HORN, H.H.; MARSHALL, S.P.; WILCOX, C. J. e RANDEL, P.E. Complete rations for dairy cattle. V. Interaction of sugarcane bagasse quantity and form with soybean mea1, urea, and starea. Journal of Dairy Science, Champaign IM, EUA, 58(9): 1320-1327, 1975 .

SOLIVA, E. Efeito de substituição do farelo de soja por le vedura, sobre a digestibilidade de raçōes para bezerros. Jaboticabal, SP. Faculdade de Ciências Agrärias e Veterinārias-UNESP, 1985. 37p. (Trabalho para graduação em Zootecnia). 
URBAN, E. Concentração de vinhaça. Rio de Janeiro. Seminário Internacional sobre Tratamento do Vinhoto - INT (4) : 45-52, 1976.

VAN SOEST, P.J. Use of detergents in the analysis of fibrous feeds. II. A rapid method for determination of lig nin. J. AOAC, 46: $839,1963$.

WARD, G.M. Potassium metabolism of domestic ruminants - a review. J. Dairy Sci., 49: 268-272, 1966. 
.66 .

\section{APÊNDICE}




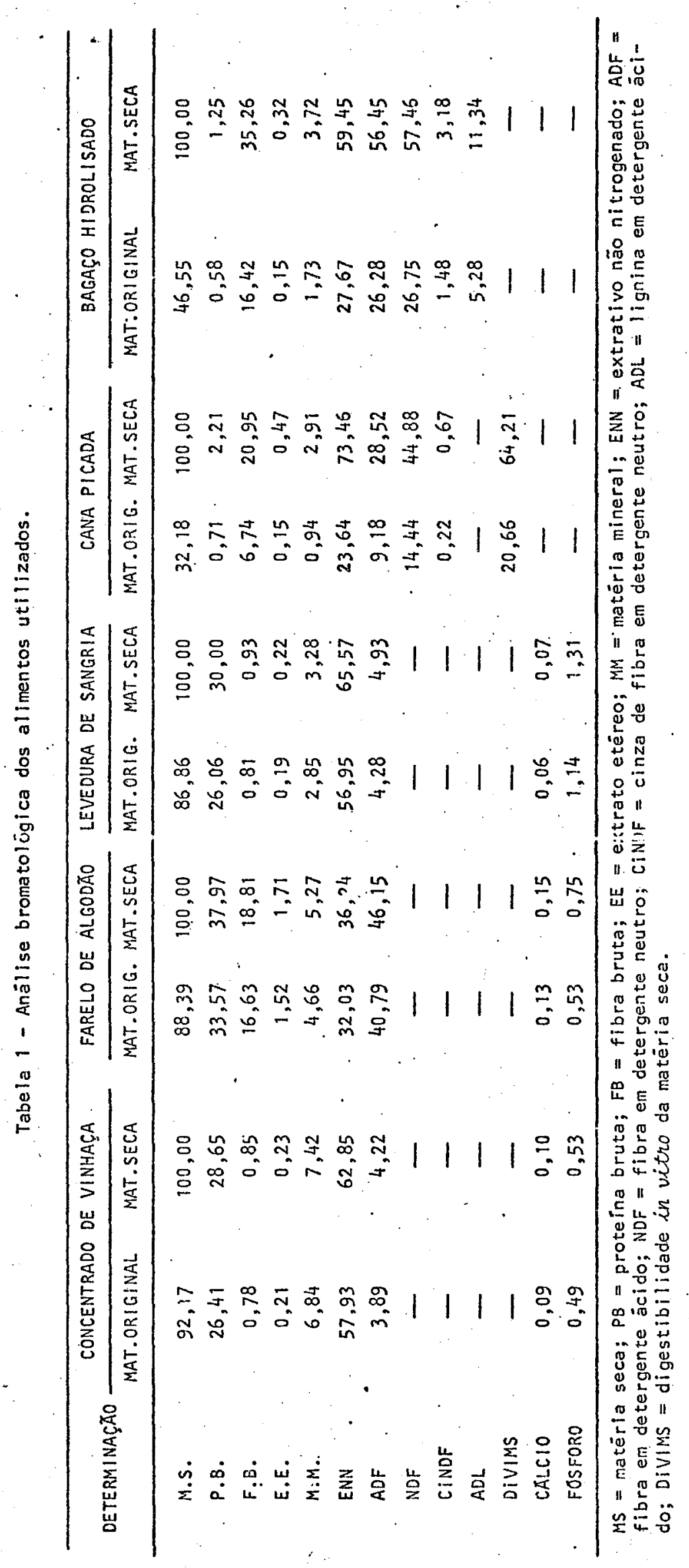




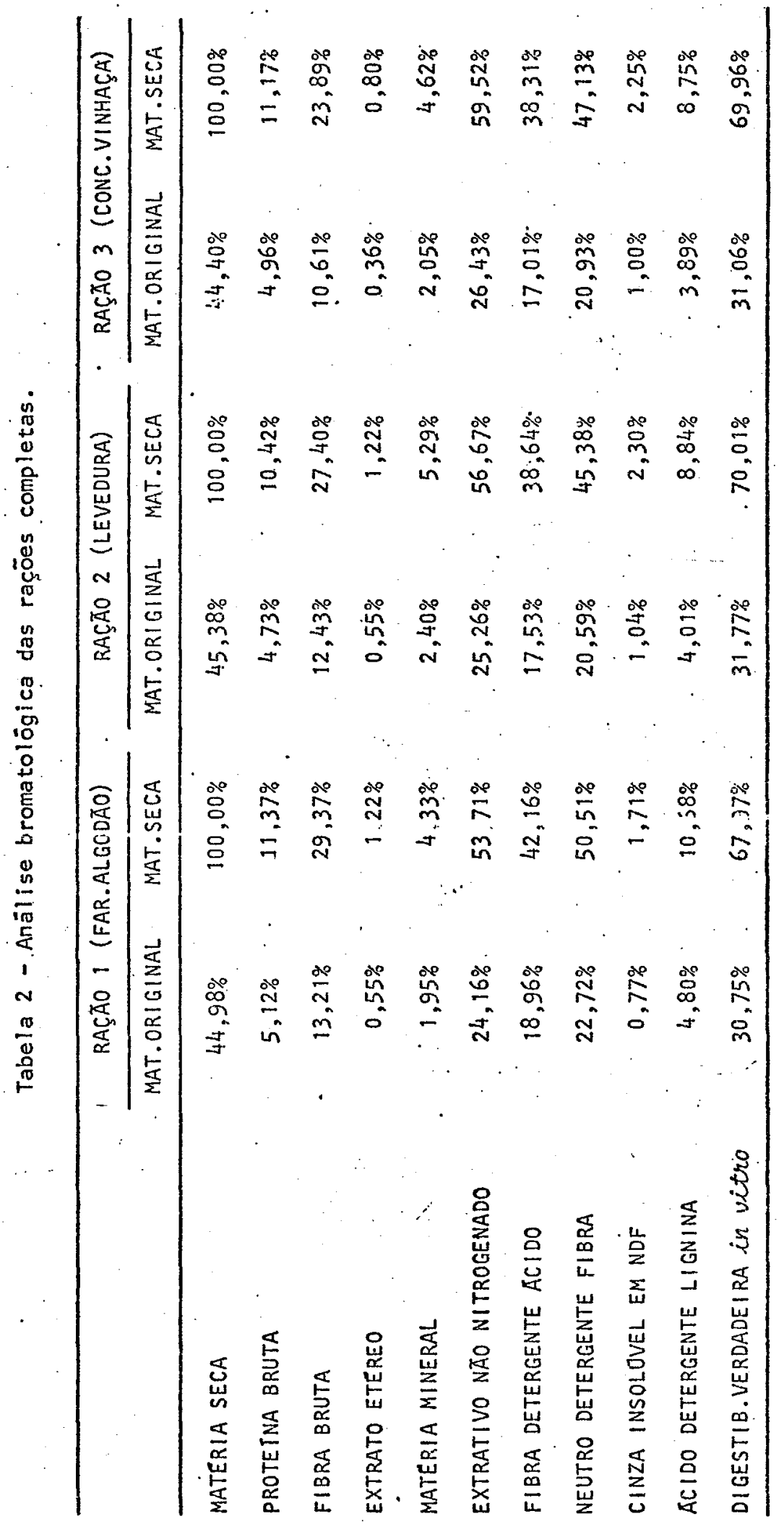


Tabela 3 - Anälise de minerais da levedura e do concentrado de vinhaça.

\begin{tabular}{lcc} 
& C. VINHAÇA & LEVEDURA \\
\hline Ca Total $(\%)$ & $0,11 \%$ & $0,08 \%$ \\
$\mathrm{P}$ Total $(\%)$ & $0,41 \%$ & $1,0 \%$ \\
$\mathrm{~K}_{2}$ O Total $(\%)$ & $1,1 \%$ & $3,0 \%$ \\
\hline
\end{tabular}


Tabela 4 - Peso inicial, peso final e ganho de peso diärio.

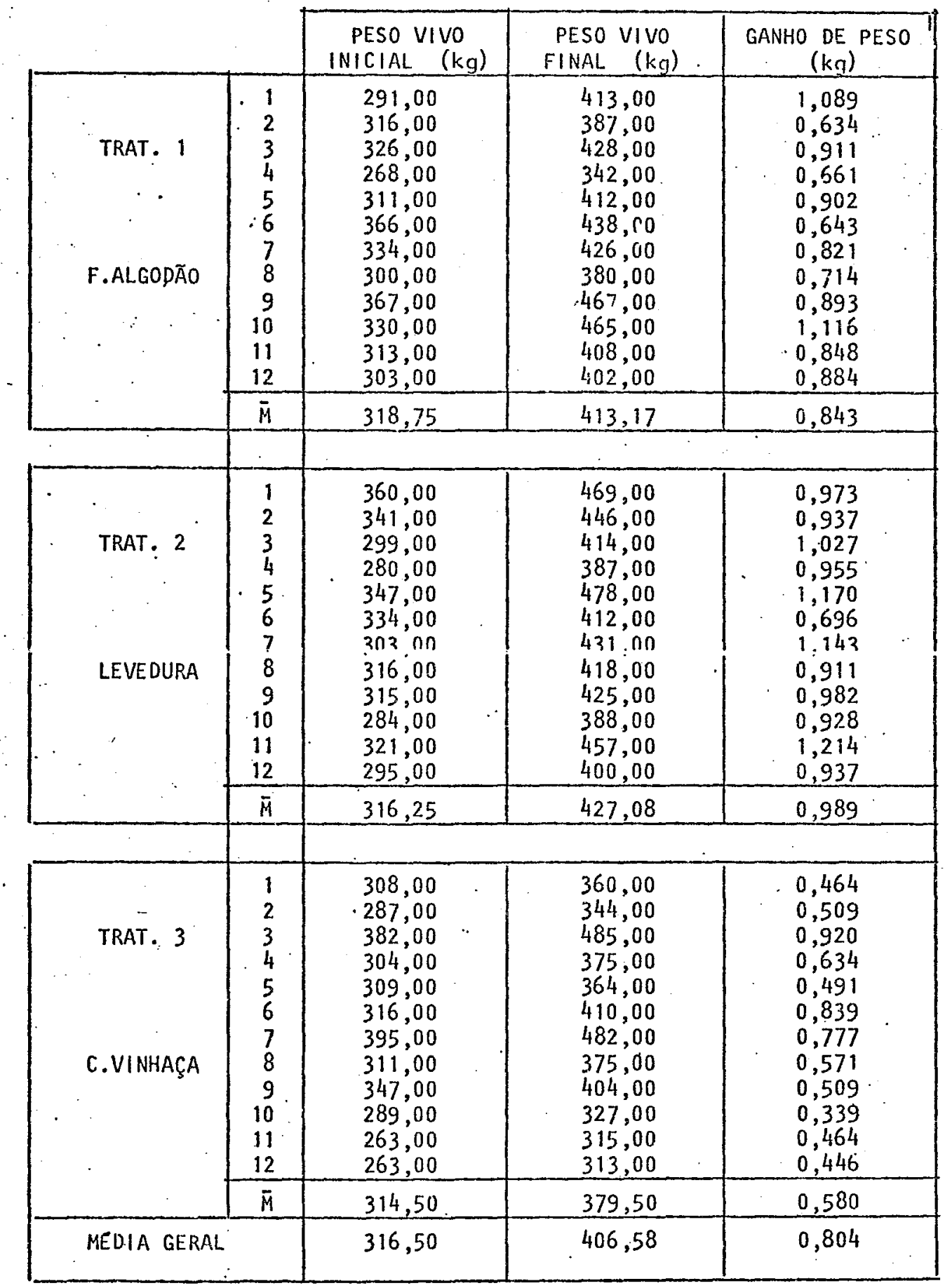


Tabela 5 - Anālise de variância - peso inicial.

\begin{tabular}{ccrrr}
\hline C.V. & G.L. & S.Q. & Q.M. & F. \\
\hline TRRAT. & 2 & 116,10 & 58,05 & 0,054 \\
RES. & 33 & $35.109,50$ & $1.063,92$ & \\
\hline TOTAL & 35 & $35.225,60$ & & \\
\hline & & & CV $=10.30 \%$
\end{tabular}

Tabela 6 - Anālise de variância - peso final.

\begin{tabular}{ccccc}
\hline C.V. & G.L. & S.Q. & Q.M. & F. \\
\hline TRAT. & 2 & $14.365,17$ & $7.182,58$ & $4,01^{*}$ \\
RES. & 33 & $59.049,58$ & $1.789,38$ & \\
\hline TOTAL & 35 & $73.414,75$ & $2.097,56$ & \\
\hline & & & CV $=10,40 \%$
\end{tabular}

* significativo ao nível de $5 \%$

Tabela 7 - Anālise de variância - ganho de peso diärio.

\begin{tabular}{ccccc}
\hline C.V. & G.L. & S.Q. & Q.M. & F. \\
\hline TRAT. & 2 & 1,032 & 0,516 & $20,64^{* *}$ \\
RES. & 33 & 0,838 & 0,025 & \\
\hline TOTAL & 35 & 1,870 & 0,053 \\
\hline
\end{tabular}

** significativo ao nivel de $1 \%$ 